\title{
Multiple Stages of Carbonation and Element Redistribution during Formation of Ultramafic-Hosted Magnesite in Neoproterozoic Ophiolites of the Arabian-Nubian Shield, Egypt
}

\author{
Mokhles K. Azer, ${ }^{1, \star}$ Hisham A. Gahlan, ${ }^{2,3}$ Paul D. Asimow, ${ }^{4}$ Heba S. Mubarak, ${ }^{1}$ \\ and Khaled M. Al-Kahtany ${ }^{2}$ \\ 1. Geological Sciences Department, National Research Centre, Cairo, Egypt; 2. Department of Geology and \\ Geophysics, King Saud University, Riyadh 11451, Saudi Arabia; 3. Geology Department, Assiut University, \\ Assiut 71516, Egypt; 4. Division of Geological and Planetary Sciences, California Institute \\ of Technology, Pasadena, California 91125, USA
}

\begin{abstract}
A B S T R A C T
We present a study of the serpentinized peridotites of the Ghadir-Mohagar-Ambaut area, Egypt. They represent the mantle section of a dismembered ophiolite, tectonically emplaced over a volcanosedimentary succession of island arc assemblages. The serpentinites are variably metamorphosed from greenschist to lower-amphibolite facies, metasomatized, and altered, including development of talc-carbonate and quartz-carbonate rocks, especially along shear zones and fault planes. Nevertheless, some samples contain relics of primary chromian spinel, olivine, and pyroxenes. Relict textures and whole-rock compositions $\left(\mathrm{Mg} \#\left[\right.\right.$ molar $\left.\mathrm{Mg} /\left(\mathrm{Mg}+\mathrm{Fe}^{2+}\right)\right]=0.92-0.93$, with low $\mathrm{Al}_{2} \mathrm{O}_{3}$ and $\mathrm{CaO}$ contents) both suggest harzburgite protoliths. The high $\mathrm{Mg \#}$ and Ni contents of relict olivine and the high $\mathrm{Cr} \#(\mathrm{molar} \mathrm{Cr} /(\mathrm{Cr}+\mathrm{Al}))$ of fresh chromian spinel cores indicate that the protoliths experienced high degrees of partial melt extraction $(\sim 34 \%-39 \%)$, well beyond the limit for exhaustion of clinopyroxene from the residue and consistent with formation in a forearc suprasubduction zone environment. The serpentinized ultramafic rocks in the study area are divided into massive serpentinite, serpentinitehosted magnesite masses, and magnesite-filled veins. The carbonation and formation of magnesite ores took place through two metasomatic stages; the first is represented by the magnesite masses and associated with deep-seated metasomatism and alteration during serpentinization, whereas the second, vein-forming stage postdates serpentinization and occurred during obduction of the ophiolite. The differences in chemical composition between massive serpentinite and serpentinitehosted magnesite masses suggest leaching of some elements and enrichment of others during carbonation; $\mathrm{MgO}, \mathrm{Cr}$, and $\mathrm{Ni}$ are depleted, whereas $\mathrm{Fe}_{2} \mathrm{O}_{3}, \mathrm{CaO}, \mathrm{MnO}, \mathrm{Nb}, \mathrm{Ba}, \mathrm{Cu}, \mathrm{Pb}, \mathrm{Sr}$, and $\mathrm{Zn}$ are enriched in the serpentinite-hosted magnesite masses, relative to the host massive serpentinite.
\end{abstract}

Online enhancements: supplemental tables.

\section{Introduction}

Ophiolite sequences provide essential information about the origin and development of oceanic lithosphere in general as well as the specific history of formation and closure of oceanic basins in a variety of tectonic environments (Dilek et al. 2000; Moores et al. 2000; Pearce 2003; Beccaluva et al. 2004; Shervais et al. 2004; Azer and Stern 2007; Furnes et al. 2014). The ophiolites of the Arabian-Nubian Shield (ANS), in particular, are important for un-

Manuscript received April 14, 2018; accepted September 13, 2018; electronically published December 7, 2018.

* Author for correspondence; email: mokhles72@yahoo.com, mk.abdel-malak@nrc.sci.eg. derstanding the formation and assembly of large tracts of juvenile crust and the events of the panAfrican orogeny. In Egypt, exposures of the northwestern corner of the ANS include Neoproterozoic ophiolites that represent fragments of oceanic lithosphere obducted onto continental crust during the collision between West and East Gondwana and the closure of the Mozambique Ocean (e.g., Pallister et al. 1988; Stern 1994; Zimmer et al. 1995; Stern et al. 2004; Azer and Stern 2007). Although generally dismembered and affected by various degrees of alteration and metamorphism (e.g., Stern et al. 2004; Azer and Stern 2007; Khalil et al. 2014; Boskabadi 
et al. 2017), these ophiolites are among the most distinctive rock units in the basement exposures of the Eastern Desert of Egypt, especially in the central and southern sectors (fig. 1).
A conspicuous feature of the ANS ophiolites is the development of carbonate minerals in their ultramafic rocks (e.g., Azer 2013; Boskabadi et al. 2017). Carbonate-altered rocks are spatially asso-

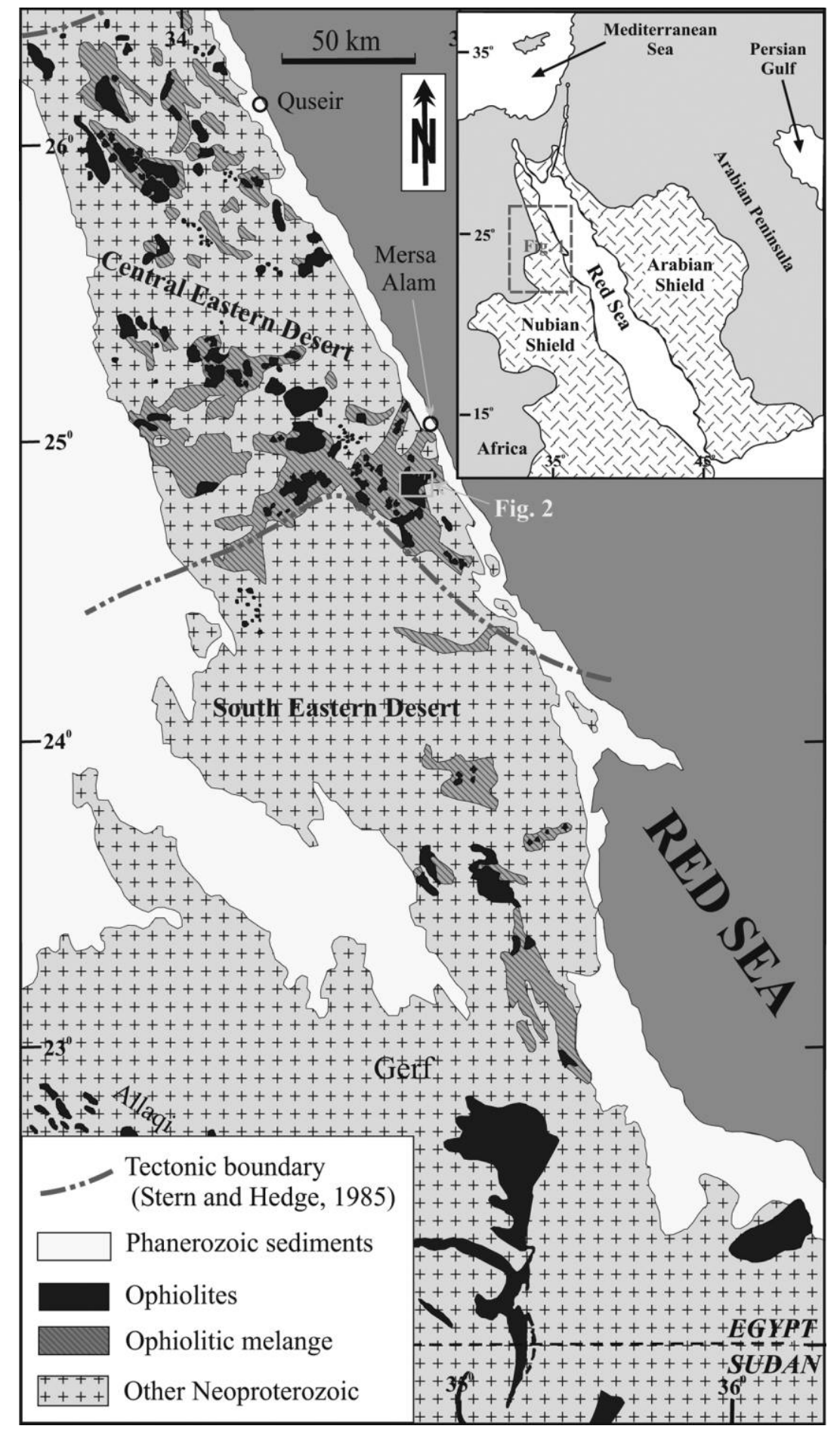

Figure 1. Regional geological map showing the distribution of late Neoproterozoic ophiolitic rocks in the central and south Eastern Desert of Egypt (modified after Shackleton 1994; tectonic boundary from Stern and Hedge 1985). The location of figure 2 is indicated. Inset map shows the location of the Eastern Desert of Egypt within the ArabianNubian Shield (Stern et al. 2004). A color version of this figure is available online. 
ciated with magnesite, talc, and gold deposits that commonly occur along shear zones and fault planes (e.g., Salem et al. 1997; Ghoneim et al. 1999, 2003; Botros 2002; Ali-Bik el al. 2012; Azer 2013; Boskabadi et al. 2017). The large volume of carbonated ultramafic rock implies significant fluxes of $\mathrm{CO}_{2}$-rich fluids, presumably during amalgamation of the ANS juvenile crust in the late Neoproterozoic era. Crucially, the source of the $\mathrm{CO}_{2}$ causing the carbonation and the timing of carbonate alteration are unknown. Furthermore, geochemical redistribution of major and trace elements between the host rocks and carbonates such as magnesite has not been well documented. In general, then, the processes associated with ultramafic mineral carbonation and the effects of these processes - in the ANS and elsewhere-remain poorly studied and understood.

This contribution aims to integrate field observations, petrography, whole-rock chemistry, and mineral composition of serpentinized and carbonated ultramafic exposures of the dismembered ophiolite in the Ghadir-Mohagar-Ambaut (GMA) area of the Eastern Desert of Egypt. The goals of the study include defining the petrogenesis and geodynamic setting of the ophiolite and its incorporation into the juvenile crust of the ANS as well as constraining the nature and timing of carbonation and alteration of ophiolitic ultramafics in the Eastern Desert of Egypt and the formation of associated ore deposits.

\section{Field Geology}

The Neoproterozoic basement complex of the Eastern Desert and Sinai constitutes the northwestern exposure of the ANS, which formed by collision between East and West Gondwana during the panAfrican orogeny (Stern 1994). A major component of the ANS, especially in the Eastern Desert of Egypt, consists of ophiolite sequences representing fragments of oceanic lithosphere obducted onto continental crust during the amalgamation of the shield. These ophiolite sequences are typically dismembered and distributed as blocks in a tectonic mélange (Shackleton et al. 1980; Ries et al. 1983; Church 1988; El Gaby et al. 1988). Sequences may include a lower "mantle" unit of serpentinized peridotite and an upper "crustal" unit of gabbro (layered and isotropic), sheeted dikes, and pillow basalts (Stern et al. 2004; Khalil et al. 2014; Gahlan et al. 2015; Obeid et al. 2016), though the full classical sequence is rarely found intact within a single mélange block.

The study area lies near the southern end of the area typically designated as the central Eastern Desert of Egypt, about $30 \mathrm{~km}$ southwest of Mersa Alam (fig. 1). It is dominated by outcrops of Neoproterozoic rocks including dismembered ophiolite, island arc assemblages, and intrusive rocks (fig. 2). Where contacts between the ophiolitic units (especially serpentinites and related quartz-carbonate rocks) and the island arc assemblages are exposed, they are thrust contacts with the island arc assemblages in the footwall. The island arc footwall rocks form a volcanosedimentary succession of slates, greywackes, and fine- to coarsegrained tuffs, with some lithic fragments of andesite. Both the ophiolite and the island arc sequence are intruded by younger granodiorites and granites, with minor tonalite.

The ophiolitic rocks in the study area are one part of the Ghadir ophiolite sequence, an outstanding example of the ophiolites of the northernmost ANS (El Sharkawy and El Bayoumi 1979; El Bayoumi 1983; Kröner et al. 1992). They are found as allochthonous blocks within a mélange (e.g., El Sharkawy and El Bayoumi 1979; Takla et al. 1982; Basta et al. 1986; Abd El-Rahman et al. 2009) once mapped as geosynclinal metasediments (El Ramly 1972). All the classic elements of the ophiolite sequence can be found within the GMA area, including serpentinized peridotites, metagabbros, sheeted dikes, and pillow lavas (Basta et al. 1986; Khalil and Azer 2007). The ophiolitic metagabbros occupy the eastern part of the study area; they form small hillocks of variable height and are melanocratic, medium grained, and black. Some gabbros are sheared and intruded by granodiorite.

The serpentinite outcrop stretching from Gebel Ghadir to Gebel Ambaut represents one of the largest and most continuous outcrops of serpentinite in the Eastern Desert of Egypt. The serpentinite is found both in a large mass in the middle of the mapped area and as small olistolith blocks within the ophiolitic mélange. In the field it displays a range of colors, usually black or greenish black. All the contacts around the serpentinite masses are tectonic and marked by strong brecciation and shearing. Serpentinites are frequently transformed into talc-carbonate and quartz-carbonate rocks (listwaenite), particularly along thrust faults and shear zones. A few chromitite lenses are encountered within the serpentinite, and narrow pyroxenite dikes cut across the serpentinites.

Magnesite bodies occur near the contacts between ultramafic rocks and siliceous country rocks and along regional faults cutting the ultramafic rocks. Magnesite ores in the GMA area form veins and stockworks (fig. $3 a$ ) as well as massive snow-white deposits (fig. $3 b, 3 c$ ) within the ultramafic country rocks. Most magnesite veins are branched (fig. $3 a$ ), and their contacts with the country rocks are sharp but irregular. The magnesite veins vary in width from a few centimeters to $1 \mathrm{~m}$. Some fault zones feature magnesite veins passing gradually upward into mas- 


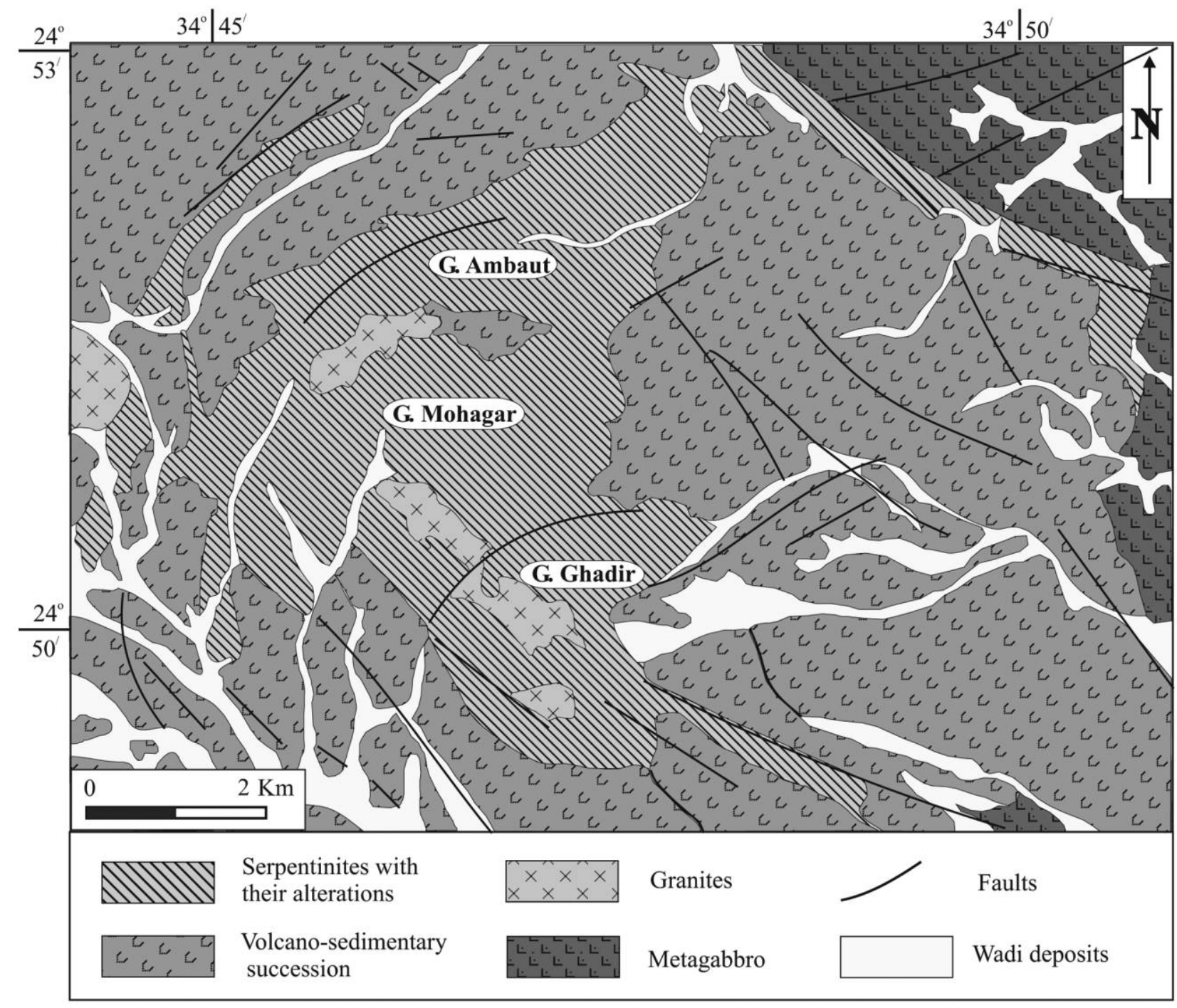

Figure 2. Geological map showing the distribution of late Neoproterozoic rocks in the Ghadir-Mohagar-Ambaut area (modified after Takla et al. 1982). G. = Gebel. A color version of this figure is available online.

sive magnesite in the hanging wall. Small magnesitefilled veinlets and stockworks, a few millimeters to $2 \mathrm{~cm}$ wide, in the altered ultramafic rocks show no well-defined preferred orientation. Some brecciated serpentinites are present within the magnesite veins (fig. 3d). Most of the veins occurring outside the main shear zones have an orientation and coarse texture suggestive of tension gashes opened with the same sense of shear as the shear zones.

In places-for example, along shear zones - the serpentinites are altered into talc-rich rocks. These are generally rather uniform in mineralogical composition but vary appreciably in fabric and color; the rocks may be massive, schistose, or gneissic and range from dark greenish gray to light gray, yellowish white, or cream colored. The talc-rich rocks are commonly soft, but they become progressively harder with increasing iron contents or abundance of carbonate minerals. They show cavernous weathering and host small veinlets of crystalline magnesite. A few nodules and irregular pockets of magnesite and dolomite with quartz are observed in the talc-rich rocks. The quartz and carbonate veins generally have a northwestsoutheast trend concordant with the foliation in the talc-rich bodies. A few secondary veinlets of sutured quartz grains are observed, interpreted to have developed along preexisting mylonite zones.

\section{Analytical Techniques}

Mineral identification was performed on thin and polished sections with a polarizing Nikon micro- 

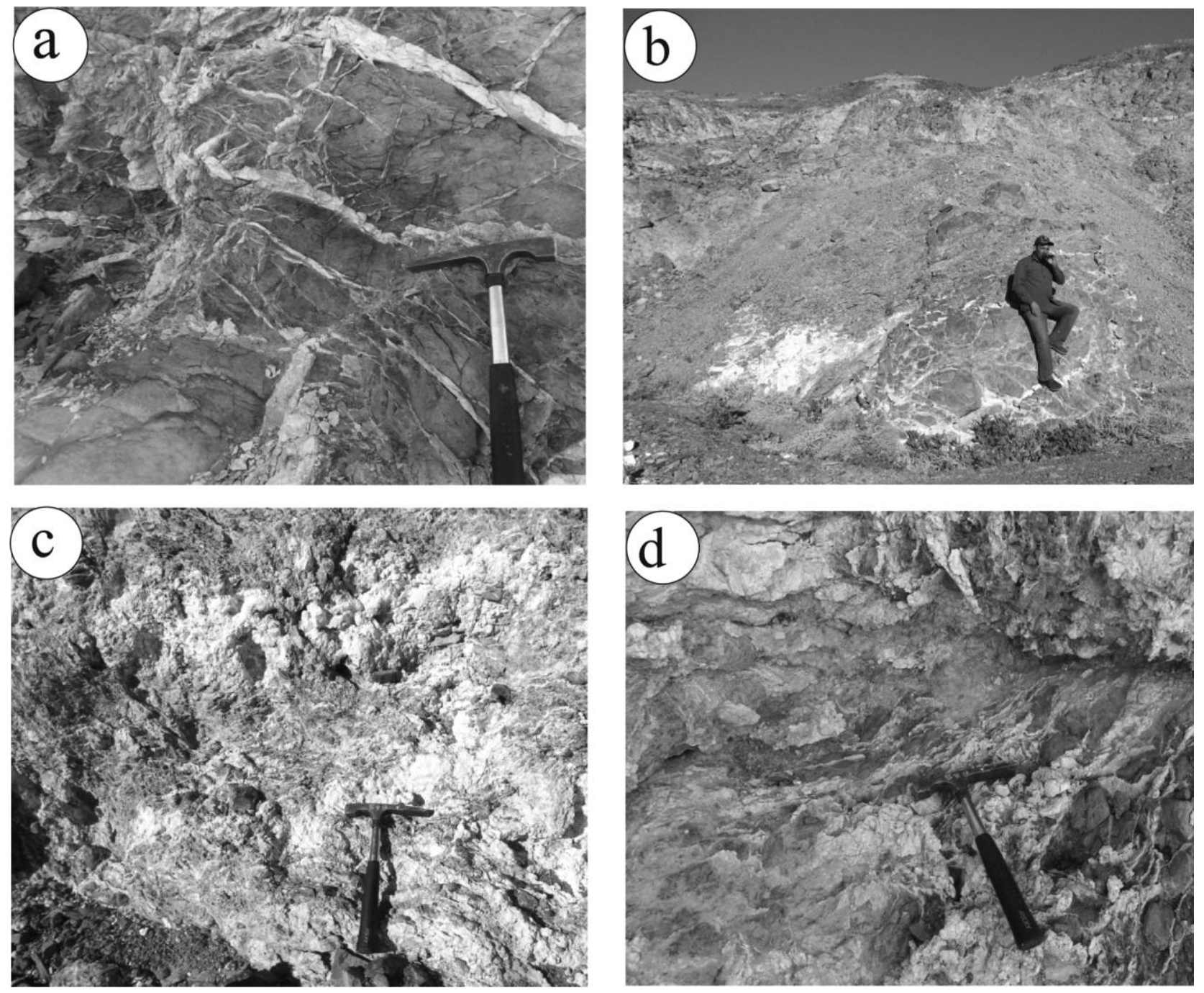

Figure 3. Field photographs from the Ghadir-Mohagar-Ambaut area. $a$, Branched veins and stockwork of magnesite. $b, c$, Snow-white deposits of massive magnesite. $d$, Brecciated serpentinite within a magnesite mass. A color version of this figure is available online.

scope and confirmed by X-ray diffraction (XRD) and an electron probe microanalyzer. Powder XRD analyses were obtained with a Bruker D8 advanced $\mathrm{X}$-ray diffractometer at the Central Metallurgical and Development Institute in Cairo, Egypt. Cu radiation and a secondary monochrometer were used at constant voltage and current of $40 \mathrm{kV}$ and $40 \mathrm{~mA}$, respectively, with a scanning speed in $2 \theta$ of $1 \%$ min.

Serpentinite samples with minimal petrographic evidence of carbonate alteration were selected carefully for whole-rock geochemical analysis. A total of 35 samples (19 serpentinites, 3 chromitites, and 13 magnesite ores) were crushed and powdered in an agate ball mill. Concentrations of major and trace elements were determined by X-ray fluorescence (XRF; ThermoARL XRF spectrometer) at the GeoAnalytical Lab, Washington State University.
Each powdered sample was weighed, mixed with two parts dilithium tetraborate flux, fused at $1000^{\circ} \mathrm{C}$ in a muffle furnace, and cooled; the resulting bead was reground, re-fused, and polished on diamond laps to provide a smooth, flat analysis surface. Reference material 650CC from USGS standard rock powder GSP2 was used as a calibration standard. Detection limits for major oxides and trace elements range from 0.001 to $0.04 \mathrm{wt} \%$ and from 0.01 to $0.5 \mathrm{ppm}$, respectively (full documentation is available online from the GeoAnalytical Lab; https://environment .wsu.edu/facilities/geoanalytical-lab/technical -notes/). The internal precision of the XRF analyses, calculated from duplicate samples, is better than $1 \%$ for most major elements and better than $5 \%$ for most trace elements (except $\mathrm{Ni}, \mathrm{Cr}$, Sc, and $\mathrm{V}$, which may scatter by up to $10 \%$ ). Loss on ignition 
(LOI) was determined by weight difference after ignition at $1000^{\circ} \mathrm{C}$. Three chromitite samples were also analyzed by XRF (Phillips PW 1400 spectrometer) at the Dipartimento di Scienza della Terra, Università degli Studi, in Rome.

The chemical compositions of the essential rockforming minerals in the serpentinites, chromitites, and magnesite ores were obtained with a fivespectrometer JEOL JXA-8200 electron microprobe housed at the Geological and Planetary Sciences Division Analytical Facility, California Institute of Technology. Operating conditions were $15-\mathrm{kV}$ accelerating voltage, a 25-nA beam current, a focused beam $(1 \mu \mathrm{m}), 20$-s on-peak counting times, and $10 \mathrm{~s}$ each on high and low background positions. Natural and synthetic mineral standards were used for calibration, and data were reduced with the CITZAF matrix correction algorithm.

\section{Petrography}

Ultramafic Rocks. We divide the ultramafic rocks in the study area into two main groups: massive serpentinites and serpentinite-hosted magnesite rocks. Massive serpentinite consists essentially of serpentine minerals $(80 \%-97 \%)$, with minor magnesite, chromite, magnetite, and chlorite. A few specks of sulfides are observed in some samples. Our XRD results indicate that the serpentine minerals are mainly antigorite, with subordinate amounts of lizardite and chrysotile.

The original textures of the ultramafic rocks have been almost completely obliterated by serpentine replacement; however, the original forms of orthopyroxene and olivine can be recognized by the presence of bastite and of mesh textures (fig. $4 a, 4 b$ ), respectively. Rare relics of olivine and pyroxene are recorded in a few samples (fig. 4c, 4d). Serpentine minerals vary in color from colorless to pale green and exhibit pseudomorphic, interpenetrating, and hourglass textures. Antigorite occurs as fibrolamellar or flame-like crystals and interpenetrating bladed crystals. Chrysotile fills veins that crosscut the antigorite matrix (fig. 4e), indicating protracted serpentinization. Locally, in the massive serpentinite, quartz occurs as brown microcrystalline infillings (fig. 4f). The brown color is due to the presence of micron-sized inclusions of goethite and hematite.

Chromian spinels in the massive serpentinite form tabular and elongated crystals with rounded rims. Primary dark-brown chromian spinel is partially altered along rims and cracks to ferritchromite and magnetite. In a few thin sections, the altered chromian spinel rims are surrounded by chlorite aureoles, including flaky, violet Cr-chlorite (kämmererite) surrounded in turn by a thin film of light-green chlorite. The petrographic relationship between kämmererite and chromian spinel suggests that the Crchlorite formed as primary chromian spinel was hydrothermally altered to ferritchromite. Secondary magnetite is common as a result of release of $\mathrm{Fe}$ upon serpentinization of olivine and pyroxene. Magnetite commonly forms rims around primary $\mathrm{Cr}$ spinels and ferritchromite. Fine-grained disseminated magnetite, locally very abundant, occurs in every serpentinite section.

The marginal parts of the massive serpentinite are sheared and display a schistosity formed by subparallel alignment of serpentine flakes. Sheared serpentinite samples are brecciated and have mylonitic and cataclastic textures. Fractures within the sheared serpentinites are filled with chrysotile, quartz, and carbonates.

Serpentinite-hosted magnesite rocks are made up of serpentine minerals ( 75-80 vol\%) and carbonates ( 10-15 vol\%), with minor chromite, magnetite, and chlorite. A few samples contain rare fibrous crystals of tremolite-actinolite. No relics of primary olivine or pyroxenes are found in this rock type. The carbonate minerals include sparse cryptocrystalline patches, fine aggregates of magnesite (fig. $4 g$ ), and rare crystals of dolomite. Texturally, most carbonates are intergrown with and appear to be coeval with serpentine minerals. There are also veinlets of magnesite crosscutting the antigorite matrix (fig. 4h).

Chromitite. Samples of the chromitite pods include both massive and disseminated chromitites, which can be clearly distinguished in hand specimen and thin section. Massive chromitite is composed mainly ( $>92 \mathrm{vol} \%$ ) of coarse-grained chromian spinel, with minor interstitial serpentine minerals and rare olivine. Chromian spinel occurs as equant euhedral to anhedral crystals. They may be unaltered or show only slight replacement by ferritchromite along grain margins and cracks. Very small olivine inclusions are observed within the chromian spinels, and traces of intergranular or fracture-filling Cr-chlorite (kämmererite) can be found. Cumulate, chain structures and banding textures, typical of magmatic crystallization (Pal and Mitra 2004), are common.

Disseminated chromitite consists of $40-70 \mathrm{vol} \%$ chromian spinel and intergranular minerals, mostly serpentine minerals, with rare olivine, chlorite, and opaques. Most chromian spinel grains in disseminated chromitite are more euhedral and smaller in size than those in the massive variety. They show highly porous rims of ferritchromite. The disseminated chromitites are much more altered than the massive chromitites, presumably because the 

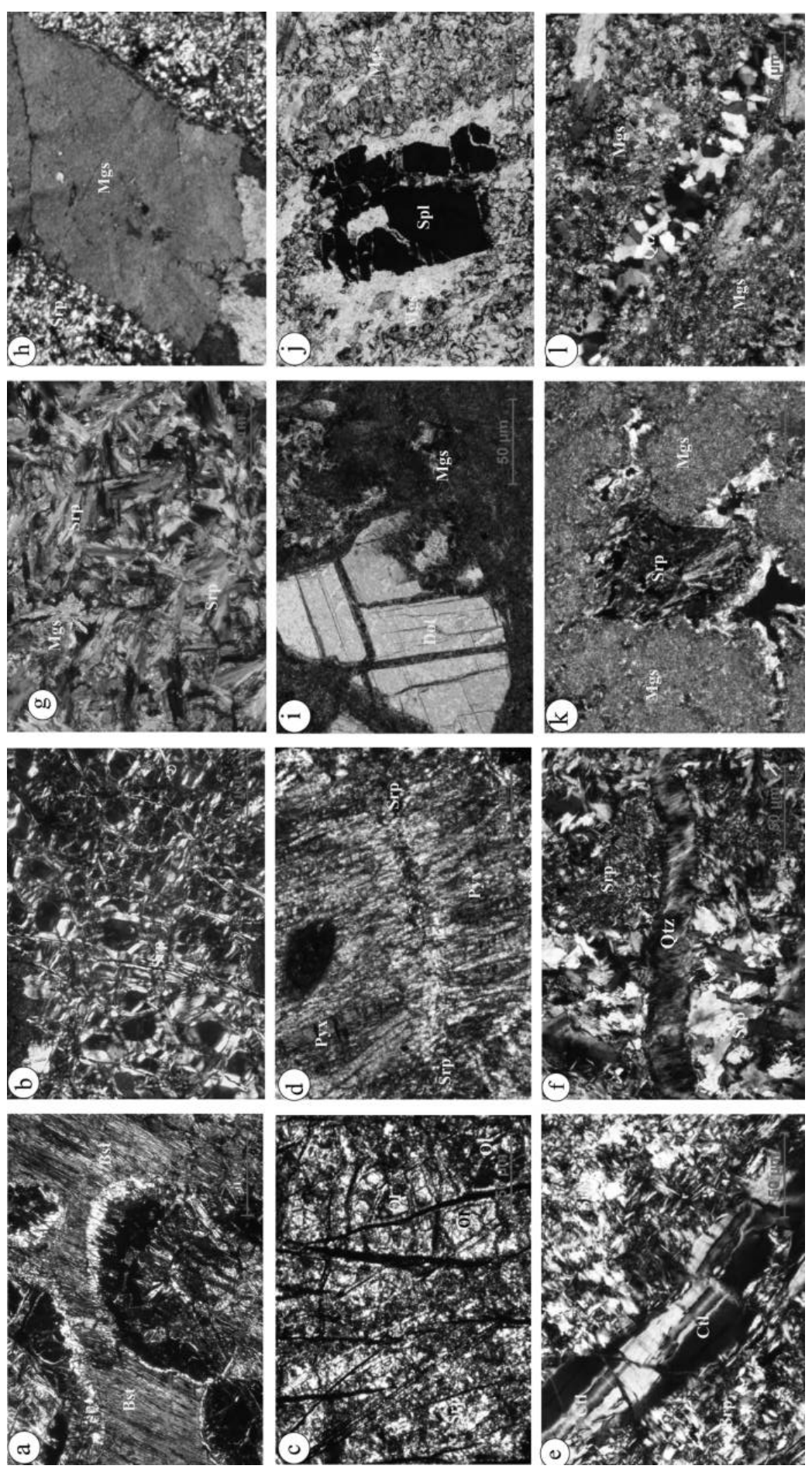
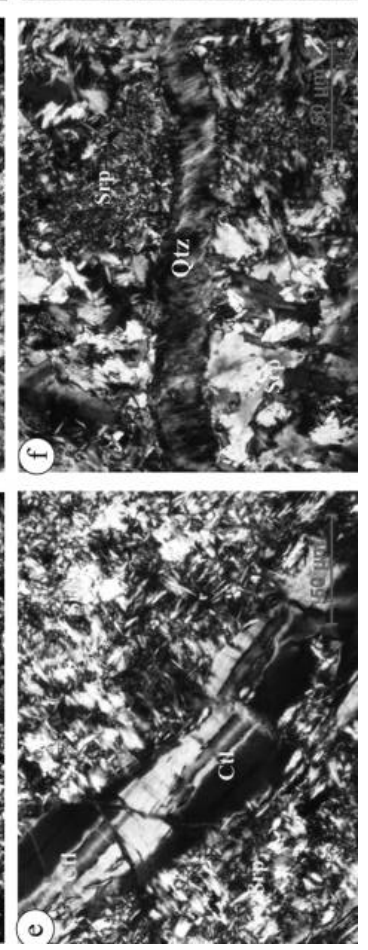

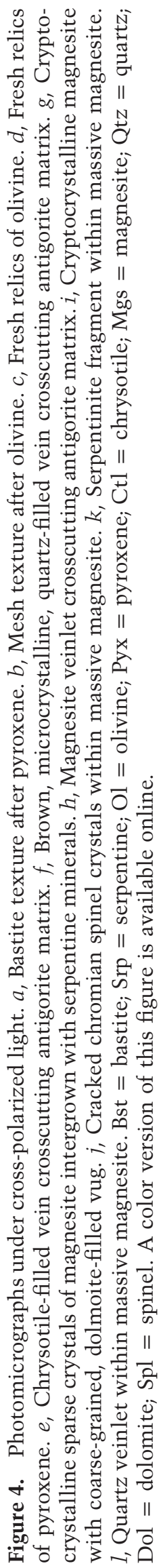


intergranular silicate phases in the disseminated variety provide more opportunity for subsolidus element redistribution.

Magnesite. Magnesite is found in a range of settings and textures in the GMA serpentinite. It occurs as sparse crystals and fine aggregates in massive serpentinite or as veins and irregular, cryptocrystalline masses (with minor, coarse-grained dolomite and calcite vug fillings) in the sheared varieties (fig. 4i). The massive magnesite may contain chromian spinel crystals similar to those in the host rock (fig. 4j) as well as angular to subangular lithic fragments of the host serpentinite (fig. 4k). Occasional quartz veinlets are found in the massive magnesite (fig. 41).

Magnesite veins are mineralogically pure and predominantly cryptocrystalline in texture, with sharp contacts with the enclosing serpentinites. Rare angular fragments of host serpentinite are observed near the margins of some veins. Outside the main shear zones there are also better-crystallized, coarse-grained magnesite veins.

Talc-Rich Rocks. Talc-rich rocks are fine grained and show brownish-yellow to reddish-brown color in thin section. They are composed essentially of talc (>75 vol\%), with subordinate serpentine, carbonate, and opaques. Talc forms fine aggregates or platy grains. Carbonates form irregularly distributed coarse aggregates. Opaque minerals include magnetite, chromian spinel, and sulfides.

\section{Mineral Chemistry}

Major-element data for silicate (serpentine, olivine, pyroxene, and chlorite), chromian spinel, and carbonate minerals in serpentinite, chromitite, and magnesite ores were determined by electron microprobe. The whole data set of mineral analyses is given in supplementary tables S1-S11, available online.

Silicate Minerals. Serpentine Minerals. Serpentine minerals were analyzed both in the serpentinite matrix (table S1) and in veins (table S2). The serpentine minerals in both matrix and veins are chemically homogeneous and compositionally near ideal. Those in the matrix have higher Mg\# (molar $\left.\mathrm{Mg} /\left(\mathrm{Mg}+\mathrm{Fe}^{2+}\right) ; 0.96-0.98\right)$ than vein-forming serpentine (0.90-0.96). Si content in the vein serpentine is 1.99-2.07 atoms per formula unit (apfu), slightly lower than that in the matrix serpentine (2.03$2.10 \mathrm{apfu})$. Matrix and vein serpentine both show low concentrations of $\mathrm{TiO}_{2}(\leq 0.04 \mathrm{wt} \%)$ and $\mathrm{Al}_{2} \mathrm{O}_{3}$ $(\leq 0.81 \mathrm{wt} \%)$.

Olivine. Rare fresh relict olivines were analyzed in serpentinites. In chromitite, both interstitial oliv- ine and discrete inclusions within chromian spinels were analyzed. Chemical compositions and structural formulae of olivine are listed in table S3. Olivine in chromitite, whether included in spinel or interstitial, is more forsteritic (Fo [forsterite] $=0.94-0.96$ ) than the fresh relics in serpentinite (0.90-0.93). The concentrations of $\mathrm{TiO}_{2}, \mathrm{Cr}_{2} \mathrm{O}_{3}$, and $\mathrm{CaO}$ are low $(\leq 0.05 \mathrm{wt} \%)$ in all analyzed olivines. $\mathrm{NiO}$ is notably higher in olivine from chromitite $(0.68-0.8 \mathrm{wt} \%)$ than in the fresh relics in serpentinite $(0.35-0.45 \mathrm{wt} \%)$, which plot along the NiO-Fo mantle array (fig. $5 a$ ). $\mathrm{MnO}$ concentration in olivine ranges between 0.07 and $0.22 \mathrm{wt} \%$ in serpentinite and is strictly lower than $0.07 \mathrm{wt} \%$ in chromitite.

Pyroxenes. Both clinopyroxene and orthopyroxene were analyzed in serpentinite (table S4). In terms of the pyroxene nomenclature of Morimoto et al. (1988), the orthopyroxene is enstatite $\left(\mathrm{Wo}_{0.9-2.1}\right.$ $\mathrm{En}_{89.5-91.3} \mathrm{Fs}_{7.48 .4}$, where Wo = wollastonite, $\mathrm{En}=$ enstatite, and Fs $=$ ferrosilite), with Mg\# = 0.92-0.93, while the clinopyroxene is mainly diopside $\left(\mathrm{Wo}_{44.0-47.0}\right.$ $\left.\mathrm{En}_{49.6-53.4} \mathrm{Fs}_{2.6-3.4}\right)$, with $\mathrm{Mg} \#=0.94-0.96$.

On the $\mathrm{CaO}$-versus- $\mathrm{Al}_{2} \mathrm{O}_{3}$ discrimination diagram, the orthopyroxene analyses plot in the field of primary mantle orthopyroxene from depleted harzburgites (fig. 5b). The low $\mathrm{Al}_{2} \mathrm{O}_{3}$ content of orthopyroxene and the high $\mathrm{Mg \#}$ of clinopyroxene are both consistent with the fields of forearc peridotites, considered to be residues after high degrees of partial melt extraction (e.g., Hamlin and Bonatti 1980; Bonatti et al. 1990; Ishii et al. 1992; fig. 5c, 5d). At such high degrees of melting, residual clinopyroxene would have been exhausted; the observed clinopyroxene therefore presumably formed in the subsolidus as the $\mathrm{CaO}$ content of orthopyroxene decreased upon cooling. Another possibility is that clinopyroxene is of metasomatic origin, which is consistent with correlations described below between normative clinopyroxene abundance and indicators of alteration.

Chlorite. Chemical compositions and structural formulae of disseminated chlorite and chloritic aureoles around chromian spinel in serpentinite are given in table S5. Chlorite in the aureoles is distinguished into green and violet Cr-bearing (kämmererite) varieties. Green chlorite in the aureoles is rich in $\mathrm{SiO}_{2}$ (28.6-30.1 wt\%) and $\mathrm{FeO}^{\mathrm{T}}(18.8-19.6 \mathrm{wt} \%)$ and depleted in $\mathrm{MgO}(18.1-19.0 \mathrm{wt} \%)$ and $\mathrm{Al}_{2} \mathrm{O}_{3}$ (17.6$18.0 \mathrm{wt} \%$ ), compared to both disseminated chlorite and kämmererite. Kämmererite is richer in $\mathrm{Cr}_{2} \mathrm{O}_{3}$ (2.6-3.7 wt\%) than either disseminated chlorite (1.0$1.9 \mathrm{wt} \%)$ or the green chlorite aureole rims (1.0$1.1 \mathrm{wt} \%)$. According to the classification scheme of Hey (1954), disseminated chlorite is mostly ripidolite, with minor pycnochlorite, whereas in the chloritic aureoles around chromian spinel, the kämmererite is 

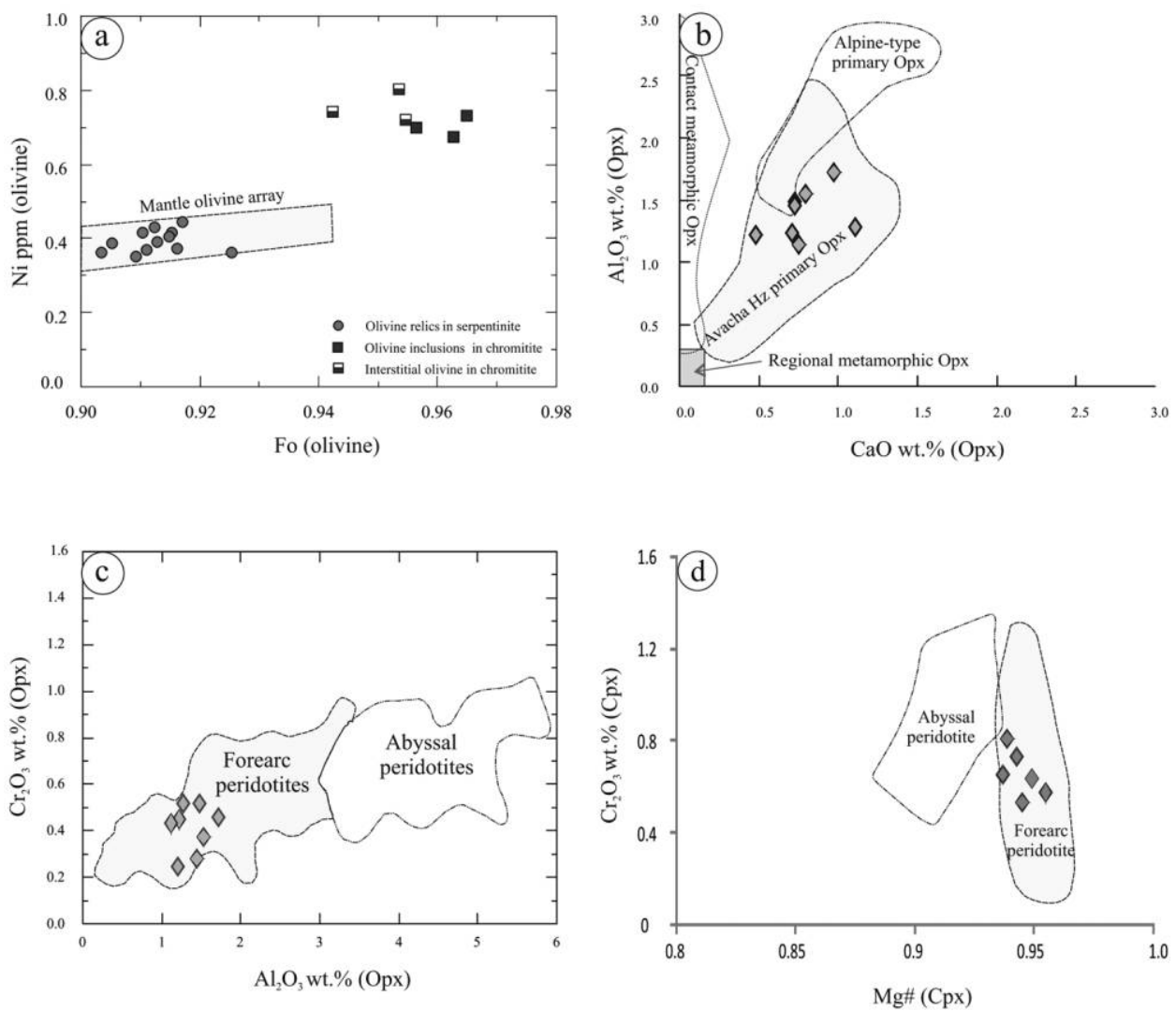

Figure 5. Chemistry of primary minerals in serpentinite and chromitite. $a$, Forsterite (Fo) versus NiO content of olivine; mantle olivine array is from Takahashi et al. (1987). b, CaO versus $\mathrm{Al}_{2} \mathrm{O}_{3}$ of orthopyroxene (Opx), compared to the fields of Avacha highly depleted harzburgite (Hz) mantle xenoliths (Ishimaru et al. 2007), orthopyroxenes from alpine-type peridotites (Arai 1980), contact-metamorphosed ultramafic rocks (Arai 1975; Frost 1975), and regionally

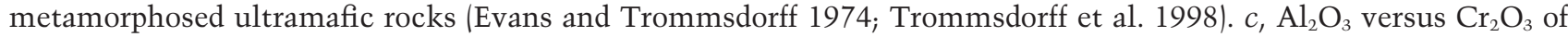
orthopyroxenes, with the abyssal peridotite field from Johnson et al. (1990) and the forearc peridotite fields after Ishii et al. (1992). d, Mg\# versus $\mathrm{Cr}_{2} \mathrm{O}_{3}$ of clinopyroxene (Cpx), compared to the abyssal-peridotite field (Hamlin and Bonatti 1980; Johnson et al. 1990; Juteau et al. 1990) and the forearc-peridotite field from Ishii et al. (1992). A color version of this figure is available online.

classified as ripidolite and the green chlorite rims are pycnochlorite.

The boundaries of chlorite stability in the presence of an aluminous phase can be used to determine the temperature of chlorite formation (e.g., Cathelineau and Nieva 1985; Kranidiotis and MacLean 1987; Hillier and Velde 1991; Bourdelle and Cathelineau 2015; Yavuz et al. 2015). Calculated temperatures for chlorite formation according to the calibrated geothermometer equation of Kranidiotis and MacLean (1987), which uses tetrahedral Al content adjusted for

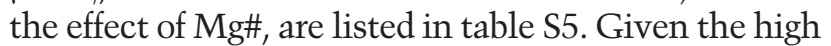
$\mathrm{Cr}$ content of associated spinel, the $\mathrm{Al}$ activity of the rock may be lower than that assumed in the calibration, leading to a systematic overestimate of the temperature. This will not affect the relative sequence of temperatures from the different textural settings and varieties of chlorite in a given rock, however. The inferred temperatures for formation of disseminated chlorite $\left(293^{\circ}-305^{\circ} \mathrm{C}\right)$ and kämmererite $\left(279^{\circ}-301^{\circ} \mathrm{C}\right)$ are higher than those for the green chlorite rims $\left(242^{\circ}-261^{\circ} \mathrm{C}\right)$, suggesting that the green chlorite aureole rims may sample a unique, late, hydrothermal stage.

Nonsilicate Minerals. Spinel Group. The chemical compositions and structural formulae of primary chromian spinel and its alteration products are given in table S6 for serpentinite, table S7 for magnesite masses, and table $S 8$ for chromitite. Primary chromian spinel shows significant heterogeneity in each sample. Disseminated chromian spinel in serpentinite is commonly altered to ferritchromite and $\mathrm{Cr}$ magnetite; less commonly, Cr-magnetite is found around chromian spinel in magnesite masses. Alteration to ferritchromite and Cr-magnetite concentrates $\mathrm{FeO}^{\mathrm{T}}$ but removes $\mathrm{Al}_{2} \mathrm{O}_{3}, \mathrm{MgO}$, and $\mathrm{Cr}_{2} \mathrm{O}_{3} . \mathrm{MnO}$ concentration in ferritchromite is higher in serpentinite $(1.1-1.9 \mathrm{wt} \%)$ than in chromitite lenses $(0.8$ 
$1.0 \mathrm{wt} \%)$ or magnesite masses $(0.7-1.0 \mathrm{wt} \%)$ as well as being higher than in other spinel varieties $(\mathrm{Cr}$ magnetite has $0.2-0.6 \mathrm{wt} \% \mathrm{MnO}$ in serpentinite and $0.2 \mathrm{wt} \%$ in magnesite masses; primary chromian spinel has $0.4-0.7 \mathrm{wt} \% \mathrm{MnO}$ in serpentinite, $0.3-0.6 \mathrm{wt} \%$ in magnesite masses, and $0.2-0.7 \mathrm{wt} \%$ in chromitite).

The variability in spinel compositions is readily visualized on the $\mathrm{Al}-\mathrm{Cr}-\mathrm{Fe}^{3+}$ triangular plot $/$ fig. 6 ; $\mathrm{Fe}^{3+}$ is estimated from $\mathrm{Fe}^{\mathrm{T}}$ and stoichiometry). Fresh chromian spinel plots along the $\mathrm{Cr}$ - $\mathrm{Al}$ join, whereas the altered phases (ferritchromite and Cr-magnetite) plot along the $\mathrm{Cr}-\mathrm{Fe}^{3+}$ join, reflecting the loss in $\mathrm{Al}_{2} \mathrm{O}_{3}$ and $\mathrm{Cr}_{2} \mathrm{O}_{3}$ and the increase in $\mathrm{Fe}_{2} \mathrm{O}_{3}$ due to alteration and metamorphism. Fresh chromian spinel in chromitite shows continuous zoning from Al- and Cr-rich cores toward rims enriched in $\mathrm{Fe}$ and $\mathrm{Cr}$, whereas chromian spinels in serpentinite and massive magnesite display an abrupt compositional change from chromian spinel core to ferritchromite and Cr-magnetite rims (fig. 6). In both cases, Mg continuously decreases from cores toward rims.

Chromian spinel in serpentinite and massive magnesite is characterized by a moderate Cr\# $($ molar $\mathrm{Cr} /(\mathrm{Cr}+\mathrm{Al})=0.61-0.70$ and 0.63-0.70, respectively), whereas chromitite features chromian spinel with a much higher Cr\# (0.77-0.89). As indicated in figure 6, primary chromian spinel has a low $\mathrm{Fe}^{3+} \#=\mathrm{Fe}^{3+} /\left(\mathrm{Fe}^{3+}+\mathrm{Cr}+\mathrm{Al}\right)<0.08$, which is considered to be a diagnostic feature of primary mantlederived spinels (Hattori and Guillot 2007; Bernstein et al. 2013). In terms of divalent cations, primary chromian spinel in chromitite has compositions that are notably more magnesian $(\mathrm{Mg} \#=0.56-0.74)$ than those of disseminated chromian spinels in serpentinite $(\mathrm{Mg} \#=0.36-0.62)$ or massive magnesite $(\mathrm{Mg} \#=0.43-0.53)$. The composition of primary chromite in the chromitite from the GMA area is similar to published analyses of chromitite lenses from other localities throughout the Eastern Desert of Egypt (Ahmed et al. 2001; Azer and Stern 2007).

Carbonates. Chemical compositions and structural formulae of carbonate minerals are given for serpentinite (table S9), massive magnesite ore (table S10), and magnesite veins (table S11). Quality control of the analyses was verified by ensuring that $\mathrm{CO}_{2}$ was sufficient to charge balance the analyzed $\mathrm{FeO}, \mathrm{MnO}, \mathrm{MgO}$, and $\mathrm{CaO}$ to bring the analytical total to $100 \pm 2 \mathrm{wt} \%$; analyses failing this test were discarded. On the basis of chemical analysis, the carbonate minerals include magnesite, ferroan magnesite, and dolomite. Magnesite is the only carbonate mineral observed in the magnesite veins, whereas both magnesite and dolomite are recorded in the magnesite masses. Magnesite from masses contains lower $\mathrm{MgO}(46.3-48.0 \mathrm{wt} \%)$ than that in

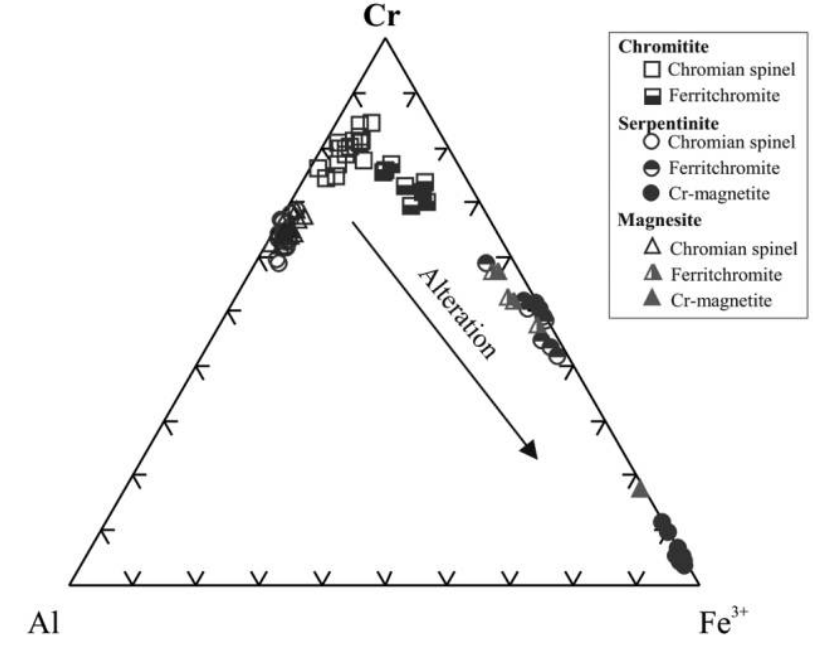

Figure 6. Ternary Cr-Al-Fe ${ }^{3+}$ plot with chromian spinels and their alteration products. A color version of this figure is available online.

the veins (48.3-49.2 wt\%). Disseminated carbonate minerals in serpentinite include magnesite, ferroan magnesite, and dolomite. Disseminated magnesite in serpentinite has $\mathrm{MgO}$ (43.4-46.2 wt\%) lower than that in either type of magnesite ore. Ferroan magnesite, by definition, is lower in $\mathrm{MgO}$ (39.5$41.0 \mathrm{wt} \%)$ and richer in $\mathrm{FeO}^{\mathrm{T}}(1.5-3.2 \mathrm{wt} \%)$ than magnesite. Dolomite, whether in massive magnesite or serpentinite, is dominated by $\mathrm{MgO}$ and $\mathrm{CaO}$, with low concentrations of other oxides.

\section{Whole-Rock Geochemistry}

Ultramafic Rocks. Whole-rock major- and traceelement data are given in table 1 for nine massive serpentinite samples and 10 serpentinite-hosted magnesite samples. Many of the incompatible trace elements are below the analytical detection limits. $\mathrm{Na}_{2} \mathrm{O}, \mathrm{K}_{2} \mathrm{O}$, and $\mathrm{P}_{2} \mathrm{O}_{5}$ are virtually absent in most analyses. All the serpentinite samples have high LOI values due to extensive hydration and carbonation; it is notable that the massive serpentinite samples have lower LOI (12.8-14.8 wt\%) than the serpentinite-hosted magnesite samples (15.1$16.4 \mathrm{wt} \%)$.

The normative mineralogy of each sample was calculated from the whole-rock major-oxide analyses (table 2). The norms of the serpentinized peridotites are dominated by olivine and orthopyroxene, consistent with harzburgite protoliths (fig. 7), whereas serpentinite-hosted magnesite samples apparently gained $\mathrm{CaO}$ during alteration, reflected in normative clinopyroxene and a shift into the lherzolite field. 


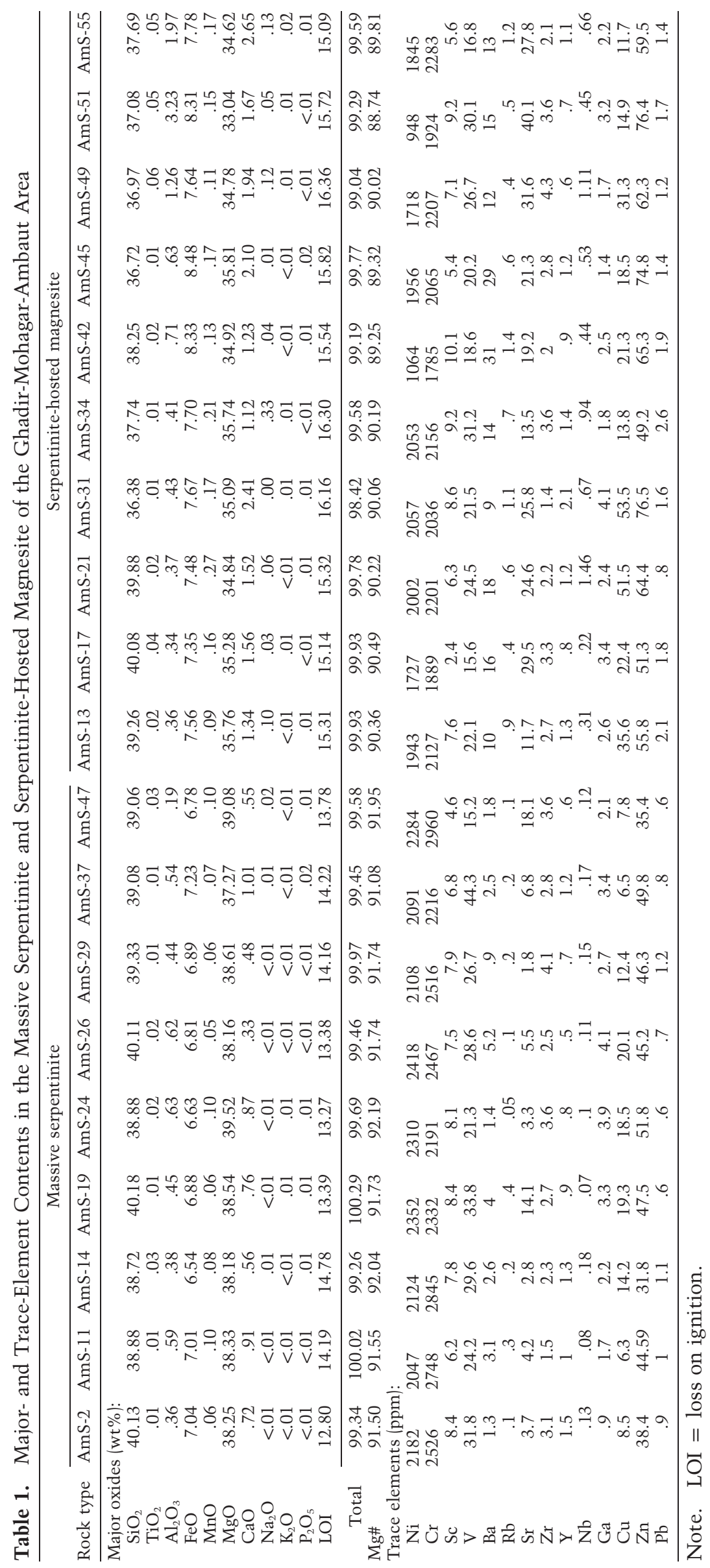

This content downloaded from 131.215.071.192 on January 17, 2019 07:44:51 AM 


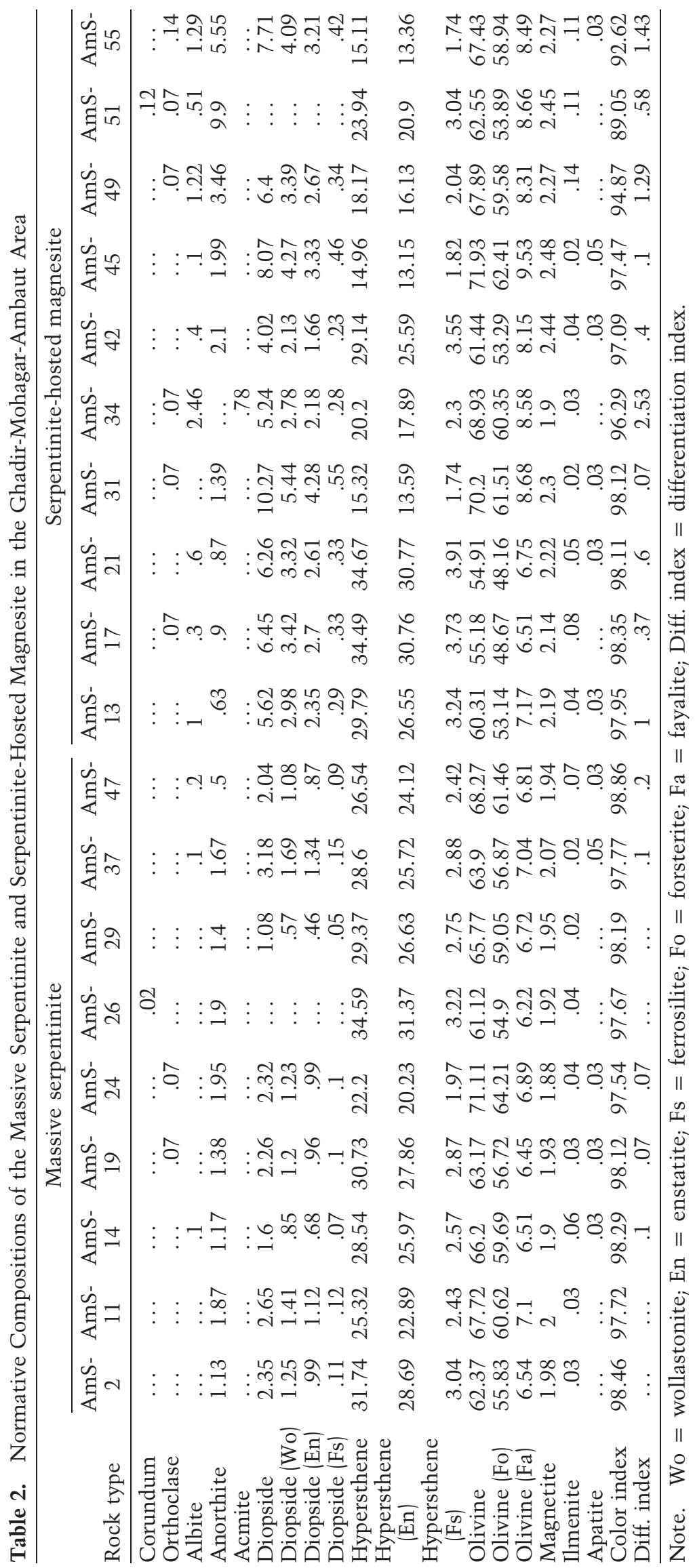

This content downloaded from 131.215.071.192 on January 17, 2019 07:44:51 AM 


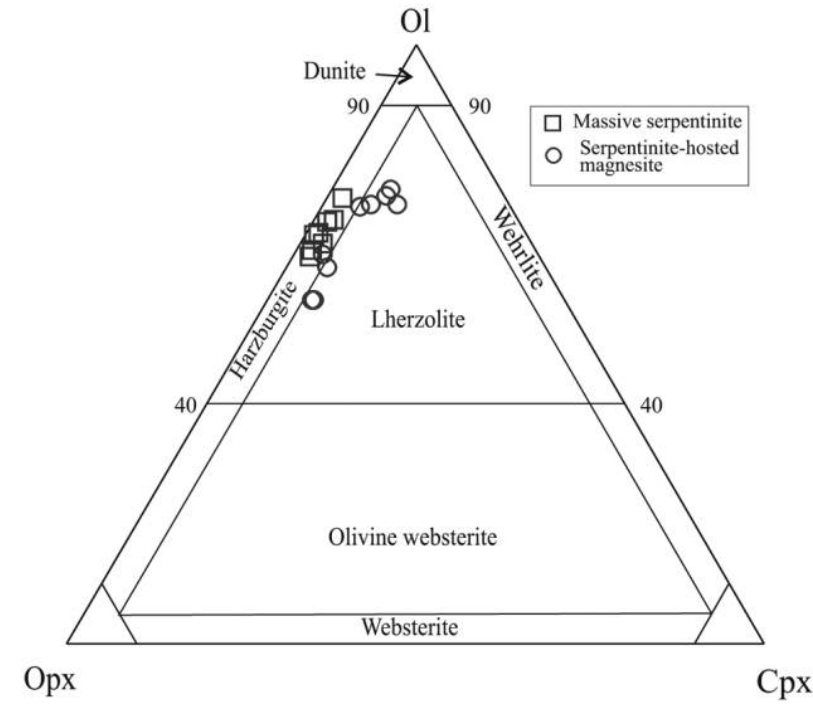

Figure 7. Ternary plot of olivine $(\mathrm{Ol})$, orthopyroxene $(\mathrm{Opx})$, and clinopyroxene $(\mathrm{Cpx})$ abundance in the normative mineralogy of massive serpentinite and serpentinite-hosted magnesite samples (ultramafic rock nomenclature from Coleman 1977). A color version of this figure is available online.

Although the compositions of the serpentinitehosted magnesite samples are broadly similar to those of the massive serpentinite samples, we can recognize significant and consistent depletion in $\mathrm{MgO}, \mathrm{Cr}$, and $\mathrm{Ni}$, accompanied by enrichment in $\mathrm{Fe}_{2} \mathrm{O}_{3}, \mathrm{CaO}, \mathrm{MnO}, \mathrm{Nb}, \mathrm{Ba}, \mathrm{Cu}, \mathrm{Pb}, \mathrm{Sr}$, and $\mathrm{Zn}$. The variations in chemical compositions in serpentinites and serpentinite-hosted magnesite are summarized in figure 8. Assuming that the serpentinite-hosted magnesite samples represent the products of alteration of protoliths similar to the associated massive serpentinite, we infer that these differences indicate which elements are leached from serpentinite during alteration and which are brought in by altering fluids. In the massive serpentinite samples, $\mathrm{CaO}$ is restricted to low concentrations that mostly covary with $\mathrm{Al}_{2} \mathrm{O}_{3}$ contents in the sense expected from melt depletion. This indicates that $\mathrm{Ca}$ metasomatism did not significantly affect the massive serpentinite samples, despite their proximity to $\mathrm{Ca}$-enriched lithologies such as serpentinite-hosted magnesite, massive and vein magnesite, talc-carbonate rocks, and quartz-carbonate rocks.

The whole-rock Mg\# of massive serpentinite samples ranges between 0.91 and 0.92 , higher than that of serpentinite-hosted magnesite samples (0.89-0.91), suggesting that there is depletion of $\mathrm{Mg}$, addition of $\mathrm{Fe}$, or both during carbonation. On the other hand, the serpentinites from the GMA area have, on the whole, a range of $\mathrm{Mg \#} \mathrm{(0.89-0.92)} \mathrm{con-}$ sistent with the Mg\# of modern oceanic peridotites (Mg\# > 0.89; Bonatti and Michael 1989) and similar to that of other ophiolites in the Eastern Desert of Egypt (e.g., Azer et al. 2013; Khalil et al. 2014; Gahlan et al. 2015; Obeid et al. 2016). It is rare to be able to compare serpentinized peridotites to fresh peridotites to assess whether serpentinization itself, though obviously accompanied by mineral-scale redistribution of $\mathrm{Mg}$ and $\mathrm{Fe}$, is accompanied by metasomatic alteration of whole-rock Mg\#. In this case, however, we have measurements of the $\mathrm{Mg \#}$ of fresh relics of both pyroxene and olivine, the dominant minerals in the harzburgite protoliths, enabling an estimate of the prealteration $\mathrm{Mg} \#$ of the whole rock as a point of comparison.

Chromitite Lenses. Only the massive chromitite was selected for major- and trace-element analysis (three samples; table 3). As expected, the chromitite samples have high $\mathrm{Cr}_{2} \mathrm{O}_{3}, \mathrm{Fe}_{2} \mathrm{O}_{3}, \mathrm{Al}_{2} \mathrm{O}_{3}$, and $\mathrm{MgO}$ contents. They are rich in $\mathrm{Ni}, \mathrm{V}$, and $\mathrm{Zn}$ but low in $\mathrm{Rb}$, $\mathrm{Ba}, \mathrm{Sr}, \mathrm{Zr}$, and $\mathrm{Nb}$. The bulk chromitite analyses have contents of $\mathrm{Cr}_{2} \mathrm{O}_{3}<50 \mathrm{wt} \%, \mathrm{FeO}^{\mathrm{T}}<20 \mathrm{wt} \%$, $\mathrm{TiO}_{2}<0.3 \mathrm{wt} \%$, and $\mathrm{MnO}<1 \mathrm{wt} \%$. These characteristics are similar to those of alpine-type podiform chromitites considered to be derived from depleted upper-mantle sources (Dickey 1976; Jan and Windley 1990).

Magnesite Ores. Whole-rock geochemical data for 13 massive and vein magnesite samples are shown in table 3. The massive and vein types are significantly different from each other. The massive magnesite type is generally higher in $\mathrm{SiO}_{2}, \mathrm{FeO}^{\mathrm{T}}, \mathrm{CaO}, \mathrm{Cr}$, $\mathrm{Ni}, \mathrm{Sr}, \mathrm{Ba}$, and $\mathrm{Pb}$ than the vein-type magnesite. Such enrichment in major oxides and trace elements not hosted by pure magnesite is consistent with and can be attributed to the observed presence of minor serpentine minerals, calcite, dolomite, and magnetite in the magnesite masses as well as the more FeO- and $\mathrm{CaO}$-rich compositions of the magnesite mineral analyses from the massive type samples. Specifically, high Cr concentrations (158-276 ppm) in the massive magnesite reflect the presence of disseminated chromian spinels. The relatively high $\mathrm{Sr}(124-203 \mathrm{ppm})$ and $\mathrm{Ba}(19-25 \mathrm{ppm})$ contents of the massive magnesite can be attributed to the presence of Ca-bearing carbonates and serpentine minerals; substitution of $\mathrm{Ba}$ and $\mathrm{Sr}$ into magnesite is quite limited because of the large ionic-radius mismatch with $\mathrm{Mg}$ (Möller 1989; Zachmann and Johannes 1989).

\section{Discussion}

The ophiolitic rocks of Egypt have been a subject of considerable research interest because they offer important clues for reconstructing the geodynamic 


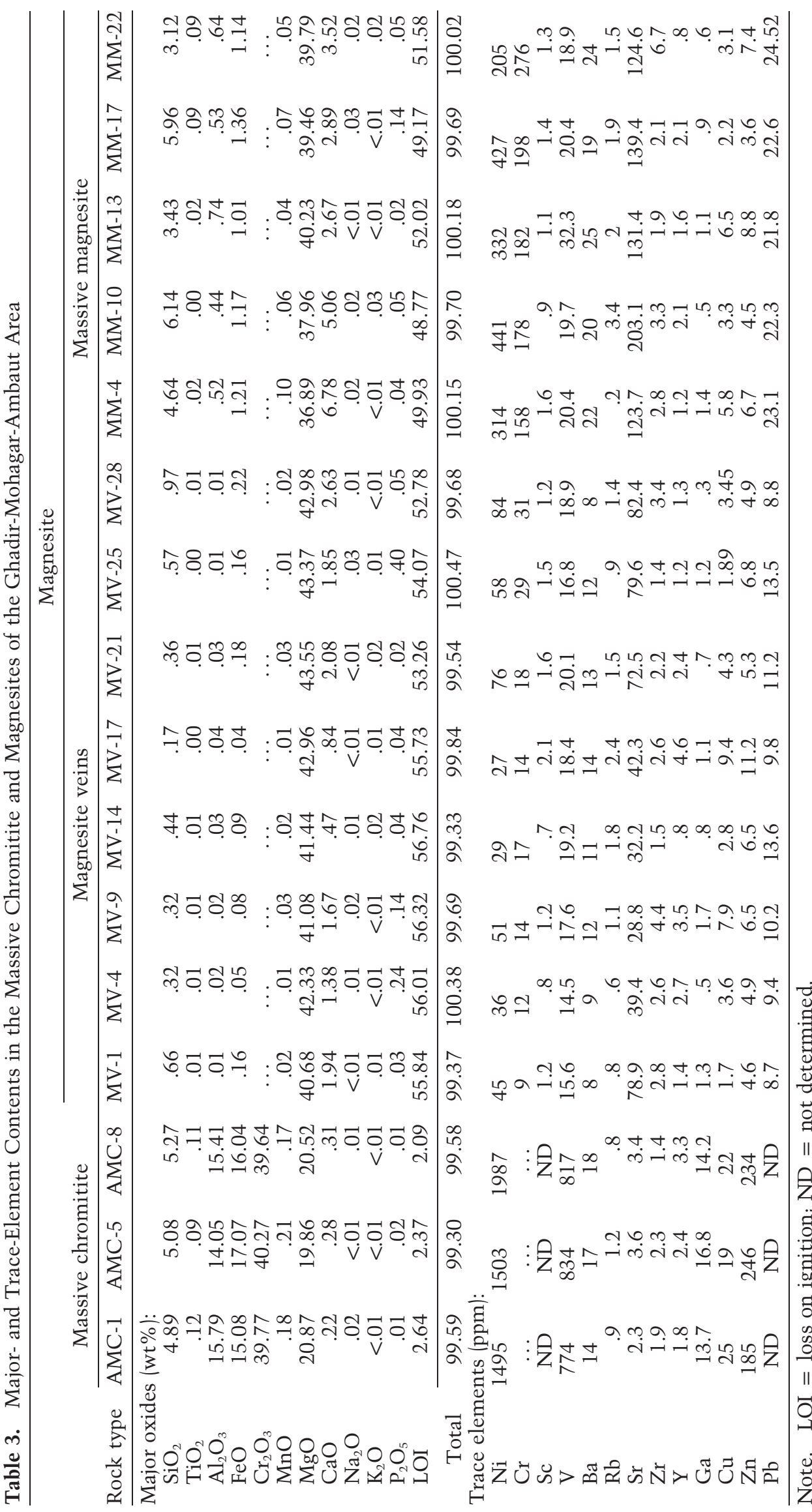


evolution of the pan-African belt (Kröner et al. 1992; Shackleton 1994; Zimmer et al. 1995; Stern et al. 2004; Azer and Stern 2007; Ali et al. 2010; Gahlan et al. 2015; Obeid et al. 2016). Most assessments of the tectonic setting for Egyptian ophiolites have focused on the bulk chemistry of lavas and gabbroic rocks; the abundant serpentinized ultramafic rocks have rarely been considered for this purpose. However, defining the tectonic setting of Neoproterozoic ophiolitic rocks on the basis of the bulk chemistry of the crustal section is challenging because of the effects of fractional crystallization and alteration (Azer and Stern 2007). Likewise, the whole-rock chemistry of highly serpentinized peridotite is of limited use in tectonic discrimination. Rather, the chemistry of preserved magmatic minerals - particularly olivine, spinel, and pyroxene-reflects the magmatic conditions and tectonic environment of ultramafic protoliths and is often robust against less-thancomplete alteration processes (e.g., Arai 1980, 1992; Dick and Bullen 1984; Beccaluva et al. 1989; Jan and Windley 1990; Barnes and Roeder 2001; Proenza et al. 2004). Hence, we focus on the compositions of relict magmatic minerals and seek to deduce the tectonic environment and petrogenesis of the serpentinites of the GMA area.

Tectonic Setting of Serpentinized Peridotites. Despite universal agreement that ophiolite sequences represent fragments of oceanic lithosphere, the differences among the detailed tectonic environments in which oceanic lithosphere can be formed are subtle and can lead to different interpretations. Thus, although Zimmer et al. (1995) inferred an open-ocean mid-ocean ridge tectonic setting for the Gerf ophiolites in the south Eastern Desert of Egypt, the past two decades have seen the development of a mounting consensus that all the ophiolitic rocks of Eastern Desert of Egypt formed in subduction-related settings (e.g., El Sayed et al. 1999; Ahmed et al. 2001; Farahat et al. 2004; Azer and Khalil 2005; Azer and Stern 2007). At a finer level of detail, while the majority of recent studies of serpentinites throughout the Eastern Desert have assigned their origin to forearc settings (e.g., Azer and Stern 2007; Khalil and Azer 2007; Abd El-Rahman et al. 2009; Azer et al. 2013; Hamdy et al. 2013; Khedr and Arai 2013; Khalil et al. 2014; Gahlan et al. 2015; Obeid et al. 2016), a few ophiolitic outcrops continue to be assigned to backarc settings on the basis of the transitional geochemical character of their volcanic sequences, between those of island arcs and mid-ocean ridges (e.g., El Sayed et al. 1999; Farahat et al. 2004; Abd ElRahman et al. 2009; Basta et al. 2011).

Our data on whole-rock and relict mineral chemistry of serpentinites from the GMA area allow us to examine the question of the tectonic setting of the Ghadir ophiolite complex by explicit comparison to corresponding data from ultramafic rocks of known geodynamic settings worldwide. Although wholerock chemistry is not the most reliable indicator, we do observe that the GMA serpentinites, like a number of other peridotite outcrops in the ANS (e.g., Stern et al. 2004; Azer and Stern 2007), plot within the highly depleted field associated with the extreme melt depletions experienced by forearc peridotites. Figure $9 a$, for example, shows that massive serpentinite samples have $\mathrm{CaO}(<0.9 \mathrm{wt} \%)$ and $\mathrm{Al}_{2} \mathrm{O}_{3}$ $(<0.6 \mathrm{wt} \%)$ contents diagnostic of forearc peridotites (fig. 9a), and the same is true for other elements, such as $\mathrm{MgO}, \mathrm{FeO}^{\mathrm{T}}, \mathrm{Ni}$, and $\mathrm{Cr}$.

Perhaps the best petrogenetic indicator for the tectonic setting of mafic and ultramafic igneous rocks is the chemical composition of primary spinel (e.g., Dick and Bullen 1984; Jan and Windley 1990; Arai 1992; Barnes and Roeder 2001; Kamenetsky et al. 2001; Sobolev and Logvinova 2005; Arif and Jan 2006). Spinels from mid-ocean ridge and backarc basin peridotites generally have $\mathrm{Cr} \#<50$ (Barnes and Roeder 2001; Ohara et al. 2002), whereas spinels in forearc peridotites generally have a higher Cr\# (up to 80 ), and those from boninites typically have a Cr\# of 70-90. Keeping in mind that alteration and metamorphism can modify spinel compositions and complicate their petrogenetic interpretation (e.g., Zhou et al. 1996; Barnes and Roeder 2001; Proenza et al. 2008; González-Jiménez et al. 2009|, we focus here only on the petrographically and chemically fresh chromian spinels in the serpentinite, chromitite, and magnesite ore from the GMA area. Analyses from serpentinite and magnesite ores have $\mathrm{Fe}^{2+} / \mathrm{Fe}^{3+}$ ratios and $\mathrm{Al}_{2} \mathrm{O}_{3}$ contents consistent with the suprasubduction zone peridotite field (SSZ in fig. 9b). On a Cr\#-Mg\# plot (fig. 9c), the chromian spinels from serpentinite and magnesite ore samples plot above $\mathrm{Cr} \#=60$, overlapping the fields of both modern forearc peridotites that experienced high degrees of melt extraction $(\sim 34 \%-39 \%)$ and other Eastern Desert ophiolites previously assigned to forearc settings (e.g., Azer and Stern 2007; Azer 2014; Khalil et al. 2014; Gahlan et al. 2015; Obeid et al. 2016).

Fresh chromian spinels in the massive and disseminated chromitite lenses are clearly distinct from those in the serpentinite and magnesite ore samples. Their Cr\#, Mg\#, and $\mathrm{TiO}_{2}$ contents all resemble those of spinels from boninite lavas (fig. 9c, 9d). Boninites, of course, are characteristic of certain stages in the evolution of the forearc of intraoceanic arcs (e.g., Murton 1989; Johnson and Fryer 1990; Bédard 1999; Beccaluva et al. 2004), and boninitic affinities have been used to support a forearc setting in a number of 

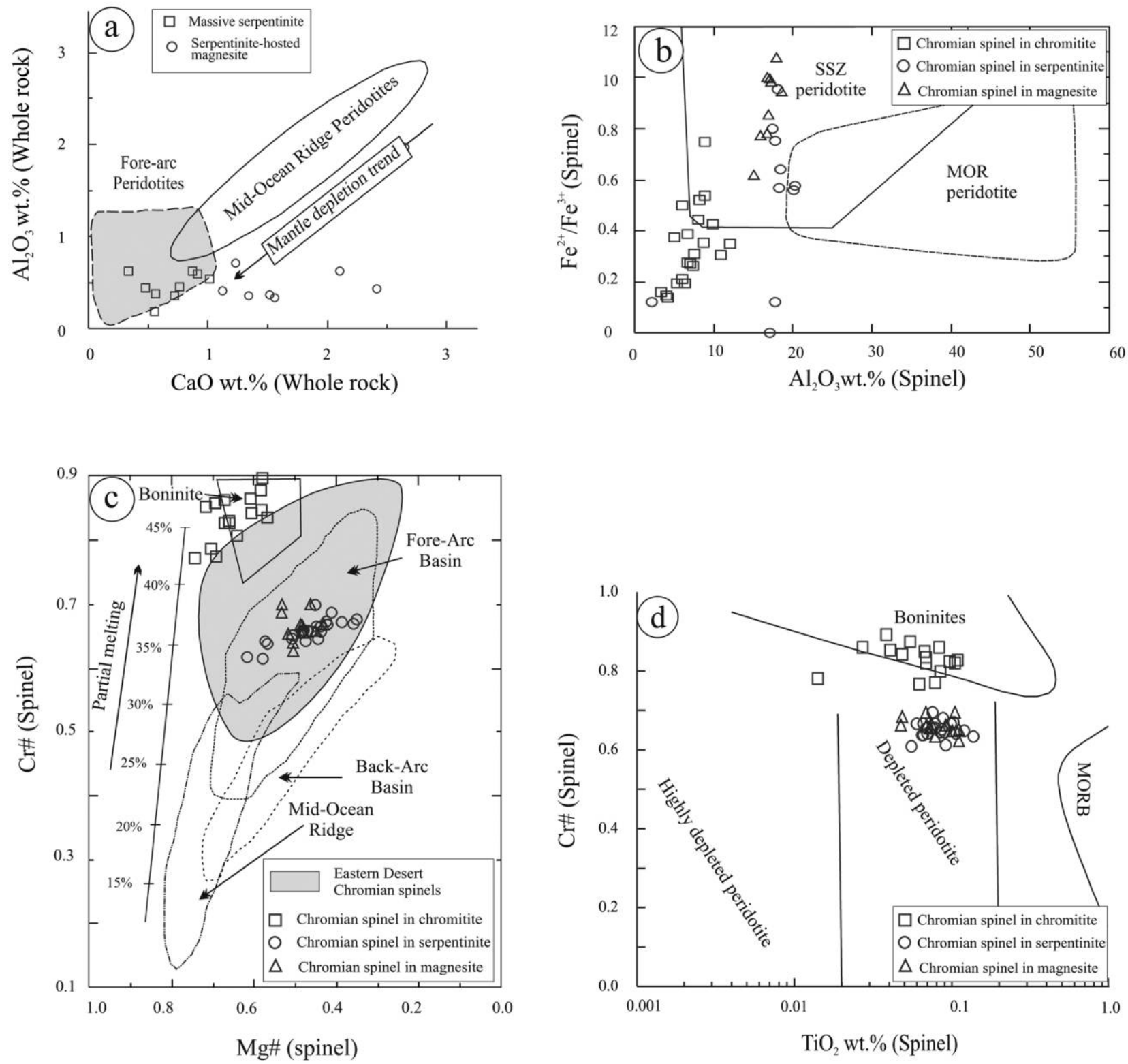

Figure 9. Discrimination diagrams for the tectonic setting of ultramafic rocks on the basis of whole-rock and spinel chemistry. a, Whole-rock $\mathrm{Al}_{2} \mathrm{O}_{3}$-versus-CaO diagram (Ishii et al. 1992). b, Spinel $\mathrm{Al}_{2} \mathrm{O}_{3}$-versus- $\mathrm{Fe}^{2+} / \mathrm{Fe}^{3+}$ diagram, showing the fields of spinel from suprasubduction zone (SSZ) and mid-ocean ridge (MOR) peridotite (after Kamenetsky et al. 2001). c, Mg\#-versus-Cr\# diagram for fresh chromian spinels (after Stern et al. 2004), with field boundaries from Dick and Bullen (1984), Bloomer et al. (1995), and Ohara et al. (2002). The field for chromian spinels in serpentinites of the Eastern Desert of Egypt is based on data from Azer and Khalil (2005), Khalil and Azer (2007), Farahat (2008), Farahat et al. (2011), Azer (2014), Khalil et al. (2014), Gahlan et al. (2015), and Obeid et al. (2016). The experimental batch melting trend, marked by degree of melting (offset for clarity), is from Hirose and Kawamoto (1995). d, $\mathrm{TiO}_{2}$-versus-Cr\# diagram for fresh chromian spinels (fields after Dick and Bullen 1984; Arai 1992; Jan and Windley 1990). MORB = MOR basalt. A color version of this figure is available online.

other Egyptian ophiolite sequences (e.g., El Sayed et al. 1999; Abdel Aal et al. 2003; Saleh 2006).

Petrogenesis. Serpentinized Peridotite. Exposed serpentinite sequences in ophiolites have witnessed a series of processes during their journey from oceanic mantle to juvenile crust and finally to surface exposure. Their chemistry, mineralogy, and texture can therefore be used, in principle, to constrain processes in all of these environments. However, each subsequent stage of their complex history partly overprints evidence of earlier stages, and so their geochemical signatures must be treated with caution to 
avoid overinterpretation. For example, the bimodal population of whole-rock $\mathrm{MgO}$ content in the GMA samples is not due to different degrees of melt extraction but rather reflects $\mathrm{MgO}$ loss during carbonation of the serpentinite-hosted magnesite samples. We attempt to minimize the influence of carbonation by comparing only the massive serpentinite samples to ultramafic rocks from various geodynamic settings as we seek to constrain the possible origin of the Egyptian serpentinites.

First, we argue that all the evidence points to a residual rather than a cumulate origin for the protoliths of the massive serpentinites. Their generally low trace-element abundances and tightly clustered $\mathrm{MgO}$ contents rule out origins involving variously fractionated picritic, boninitic, or komatiitic magmas (Umino and Kushiro 1989; Arndt et al. 2008; Wood and Turner 2009; Fiorentini et al. 2011; Szilas et al. 2014). Cumulates derived from anhydrous magmas at low pressure would crystallize plagioclase after olivine, whereas only olivine and orthopyroxene are abundant in the GMA suite. Although $\mathrm{H}_{2} \mathrm{O}$ suppresses the crystallization of plagioclase, it generally favors wehrlitic rather than harzburgitic cumulates (Müntener et al. 2001; Feig et al. 2006; Müntener and Ulmer 2006), and the low $\mathrm{CaO}$ and $\mathrm{Al}_{2} \mathrm{O}_{3}$ whole-rock contents of the GMA suite rule out a wehrlite protolith. Although sills of intrusive harzburgite can be found in the crustal section of, for example, the Bay of Islands ophiolite (Bédard 1991), the current suite lacks any evidence of such an origin, being a large mass of homogeneous serpentinite without any plagioclase, gabbro xenoliths, or pyroxenite reaction rims.

The range of whole-rock $\mathrm{Mg} \#$ in the uncarbonated massive serpentinites, $0.91-0.92$, can be compared to the Fo content of fresh relict olivine (0.90-0.93) and of fresh relict orthopyroxene (0.92-0.93), to assess both the effect of serpentinization and metamorphism on whole-rock $\mathrm{MgO}$ and $\mathrm{FeO}^{\mathrm{T}}$ and the nature of the harzburgite protoliths. Generally speaking, the observed whole-rock $\mathrm{Mg \#}$ is within the range spanned by the mineral relics but has a more restricted distribution, as might be expected from averaging over many grains. We do not, therefore, have any evidence that whole-rock Mg\# changed during serpentinization, despite the obvious small-scale redistribution of $\mathrm{Mg}$ and Fe from primary mafic minerals to secondary serpentines and oxides. The compositions of fresh olivine and pyroxene relics from the GMA area serpentinites support a primary mantle origin (fig. $5 a, 5 b$ ) and are consistent with the whole-rock chemical indicators showing that the protoliths were highly depleted harzburgites.

The high Cr\# $(>0.60)$ of fresh chromian spinels in the GMA serpentinites requires either high degrees of partial melting extraction or extensive melt-rock interaction (Parkinson and Pearce 1998; Pearce et al. 2000; Matsukage and Kubo 2003; Okamura et al. 2006). However, the low $\mathrm{TiO}_{2}$ contents $(0.04$ $0.16 \mathrm{wt} \%$; average: $0.09 \mathrm{wt} \%$ ) of the spinels is not consistent with the products of melt-rock reaction, which tend to be Ti rich. The assignment of the fresh chromian spinels to depleted residual harzburgite protoliths is confirmed by plotting them in a Cr\#versus- $\mathrm{TiO}_{2}$ diagram (fig. 9d), which places them clearly in the field of chromian spinels from forearc basin settings.

Magnesite. Magnesite $\left(\mathrm{MgCO}_{3}\right)$ can be formed both in sedimentary environments and by alteration of ultramafic magmatic rocks (e.g., Pohl 1990; Abu-Jaber and Kimberley 1992a, 1992b; Zedef et al. 2000; Lugli et al. 2002; Beinlich et al. 2012; Kadir et al. 2013). The formation of nearly pure magnesite ores, talc-carbonate rocks, and listwaenite from serpentinite protoliths requires a substantial input of externally derived $\mathrm{CO}_{2}$ at a relatively elevated temperature in order to achieve nearly complete replacement of the original serpentine minerals. In the Eastern Desert of Egypt, all the known magnesite deposits are associated with serpentinized ultramafic rocks and show evidence of control by structural features that allowed and localized the influx of fluids, but the published literature on such deposits is sparse and leaves open questions about their timing and detailed origin (e.g., Newton and Stern 1990; Stern and Gwinn 1990; Azer 2013; Boskabadi et al. 2017; Hamdy and Gamal El Dien 2017). Early C, O, and Sr isotope investigations of carbonate veins from central Eastern Desert of Egypt suggest a mixed mantle and sedimentary carbon source (Stern and Gwinn 1990), whereas more recent stable-isotope $(\mathrm{C}, \mathrm{O}, \mathrm{H})$ studies indicate an exclusively mantle-derived carbon source (e.g., Boskabadi et al. 2017; Hamdy and Gamal El Dien 2017). Yet some magnesite veins in the Eastern Desert have been attributed to an influx of $\mathrm{CO}_{2}$ from metamorphic degassing that penetrated serpentinized peridotite along tectonic fractures during or even after exhumation to upper crustal levels (e.g., Shukri and Lotfi 1959; Salem et al. 1997; Ghoneim et al. 1999, 2003; Hamdy and Lebda 2007).

In the GMA area, we find evidence for at least three different styles and intensities of carbonation of serpentinized peridotites, indicating multiple stages of infiltration and alteration by $\mathrm{CO}_{2}$-rich fluids. The three styles are represented by diffuse partial alteration of serpentinite to serpentinite-hosted magnesite, by concentrated masses of magnesite, and by veins of magnesite. The available data indicate differences between the sources of the massive and vein-type magnesite ores. 
Mineralogical, structural, and geochemical data indicate that both serpentinite-hosted magnesite and magnesite masses were formed by alteration of ultramafic rocks involving leaching of magnesia and other components by $\mathrm{CO}_{2}$-rich solutions and deposition of magnesite in pore space opened by loss of solid volume. An origin of the massive magnesite by replacement of ultramafic rocks is supported by the presence, in the magnesite masses, of spinel similar in composition to that in the host serpentinite, of some silicate minerals such as serpentine and talc, and of angular to subangular fragments of serpentinite. These magnesite types reflect deep-seated metasomatism and alteration; they may be synchronous with serpentinization, and they may be associated with the final stages of emplacement of the mantle section into forearc oceanic lithosphere. The $\mathrm{CO}_{2}$-rich fluids for the diffuse and massive magnesite may be derived from decomposition of carbonates in the subducted slab underlying the original forearc. A carbon isotope study would be helpful to confirm the origin of the carbon. GMA dolomite and calcite vug fillings associated with massive magnesite likely formed by replacement of magnesite in the presence of fluids that evolved toward increasing $\mathrm{Ca}^{2+} / \mathrm{Mg}^{2+}$ activity ratios.

The magnesite veins have an origin different from that of the massive magnesite. Texturally, the field evidence indicates that the magnesite veins formed after serpentinization and yet do not represent in situ metasomatism or replacement of serpentinite. They fill tectonic fractures that likely represented conduits for ascending or circulating hydrothermal solutions rich in $\mathrm{CO}_{2}$ and $\mathrm{Mg}^{2+}$. Ascent and decompression of such solutions leads to a supersaturation of magnesite, most likely at temperature below $300^{\circ} \mathrm{C}$, as a higher temperature would promote formation of talc (Johannes 1970), and this is not observed. Such an origin is consistent with the following observations: (1) the veins are monomineralic magnesite and predominantly cryptocrystalline in texture, (2) angular fragments of serpentinite host are rare and exclusively restricted to vein margins, and (3) there are no relics of silicate minerals such as chromian spinel and serpentines in magnesite veins (which explains why the veins have lower concentration of $\mathrm{Cr}$ than the massive magnesite). The cryptocrystalline texture of magnesite indicates a rapid addition of $\mathrm{CO}_{2}$-rich fluids and precipitation of magnesite from solutions under near-surface conditions (Abu-Jaber and Kimberley 1992a, 1992b).

Chromitite Petrogenesis. The petrogenesis of chromitite pods in various tectonic settings has been a subject of considerable interest and heated debate for many years (e.g., Lago et al. 1982; Roberts 1988). In recent years, a model of podiform chromitite formation through melt-peridotite interaction and subsequent melt mixing has become widely accepted (e.g., Arai 1992, 1997; Arai and Yurimoto 1994; Zhou et al. 1996), but opinions differ as to whether this is more typical in mid-ocean ridge (Nicolas 1989) or subarc (Arai and Yurimoto 1994; Arai 1997) settings. Both the massive and the disseminated chromitite ores in the GMA area display magmatic textures (e.g., Nicolas 1989; Roberts and Neary 1993), and their chromian spinel chemistry lies in the field of boninites (fig. 9c, $9 d)$. In outcrop, the GMA chromitites are surrounded by massive serpentinites of dunite parentage that grade outward to sheared serpentinites of harzburgite parentage. This zonal pattern has been recognized elsewhere and has been attributed to focused meltperidotite interaction (e.g., Arai and Yurimoto 1994; Zhou et al. 1996). In addition, the prominent increase in spinel $\mathrm{Cr} \#$ from the serpentinized peridotite host to the chromitite pods (fig. $9 \mathrm{c}$ ) is consistent with the model of increased intensity of melt-rock reaction in the pods (e.g., Zhou et al. 1996). The suggested model for formation of the GMA chromitite pods, then, begins with interaction between ascending melt and overlying harzburgite, leading to dissolution of orthopyroxene and formation of replacive dunite and secondary silica- and chromium-rich melt (e.g., Kelemen 1990; Arai 1997). Subsequent mixing of this secondary melt with a new influx of primitive melt results in a hybrid melt oversaturated with spinel component (e.g., Arai and Abe 1995) and subsequent precipitation of chromite (e.g., Roberts 1988; Arai and Abe 1995). In this model, the GMA chromitites preserve-despite subsequent deformation, transposition, and alteration - the cores of conduits along which magma migrated through the shallow upper mantle.

Arai and Yurimoto (1995) argue that low total pressure, high water activity, high temperature, and a compressional stress regime are the most favorable conditions for upper-mantle chromitite formation. To the extent that proximity to metagabbro outcrop can be used as a proxy for depth below the paleomoho, the GMA chromitites appear largely restricted to the shallowest part of the mantle section, consistent with a low-pressure origin. Furthermore, as argued above, the composition and mineral chemistry of the serpentinite hosts and the chromian spinel chemistry of the chromitites themselves (fig. 9) all suggest a forearc suprasubduction zone setting, which is likely to experience a compressional stress regime for much of its evolution.

Chromitite pods in the GMA serpentinite outcrop are relatively small ( $\leq 1 \mathrm{~m}$ length) and few in number. Arai (1997) has argued that the size and density of 
chromitite pods in ophiolitic mantle sequences are correlated with the chemistry of the host peridotite protolith, particularly with Cr\# in spinel. Moderately refractory peridotites with spinel Cr\# of between 0.4 and 0.6 are associated with the occurrence of abundant, large-scale ophiolitic chromitite pods, whereas the most refractory peridotite hosts, with spinel Cr\# $>0.7$, are free of chromitite pods (Arai 1997). The GMA occurrence is entirely consistent with this global correlation; the serpentinized peridotite host is highly but not extremely refractory, with spinel Cr\# in the range 0.6-0.7, and they host only sparse, small-scale chromitite pods.

Metamorphism and Alteration. Ophiolitic rocks throughout the Eastern Desert of Egypt have experienced protracted histories since their formation, leading to various degrees of metamorphism, deformation, and alteration. The metamorphic grade is most often lower-greenschist facies but in some places may reach amphibolite grade (e.g., Azer and Khalil 2005; Farahat 2008; Abu El Ela and Farahat 2010; Khedr and Arai 2013; Gahlan et al. 2015). Serpentinization of the ultramafic members of all the dismembered Egyptian ophiolites is pervasive and is often accompanied by a first cycle of carbonation, reflecting the activity of $\mathrm{CO}_{2}$ in the serpentinizing fluids (Stern and Gwinn 1990; Boskabadi et al. 2017). Infiltration of further $\mathrm{CO}_{2}$-rich fluids during deformation is shown by the localization along shear zones and fault planes of further alteration of serpentinite, including recrystallization to serpentine minerals and formation of listwaenite, talc-carbonate rocks, and magnesite deposits.

Serpentine minerals may form by hydration of primary mafic phases, by recrystallization of earlier serpentine phases during prograde metamorphism, or, in some cases, by retrograde hydrothermal alteration of ultramafic rocks metamorphosed under dry conditions (Deer et al. 1992). Antigorite is the most common prograde reaction product, while lizardite is the most common retrograde reaction product. Petrographic and XRD results indicate that the serpentinites of the GMA area are dominated by antigorite, with subordinate lizardite and chrysotile. The simplest interpretation would be that the protoliths were serpentinized during heating and burial (Moody 1976; Deer et al. 1992), but multistage histories, such as retrograde formation of chrysotile and lizardite followed by a second cycle of prograde recrystallization to antigorite, cannot be excluded (Azer and Khalil 2005). The dominance of antigorite over chrysotile and lizardite suggests that the serpentinites record temperatures of $400^{\circ}-600^{\circ} \mathrm{C}$ during hydration at elevated pressure (Evans 2010).
Spinel-family minerals in the Egyptian ophiolites preserve essential records of nearly every stage of the magmatic and postmagmatic history of these ultramafic rocks. Whereas primary chromian spinel cores record the conditions of melt extraction before emplacement in the lithosphere, their partial replacement by ferritchromite and Cr-magnetite accompanies serpentinization, tectonism, and greenschist-to-amphibolite-grade metamorphism (Thalhammer et al. 1990; McElduff and Stumpfl 1991; Khudeir et al. 1992; Azer and Khalil 2005; Khalil and Azer 2007; Farahat 2008; Azer 2014; Khalil et al. 2014; Gahlan et al. 2015; Abdel-Karim and El-Shafei 2018). Low $\mathrm{Fe}^{3+}$ contents in the primary chromian spinel indicates melt extraction and equilibration at relatively low oxygen fugacity, whereas high $\mathrm{Fe}^{3+}$ in the ferritchromite and $\mathrm{Cr}$ magnetite rims suggest increasingly oxidizing conditions during metamorphism (e.g., Murck and Campbell 1986; Mellini et al. 2005; González-Jiménez et al. 2009; Anzil et al. 2012).

In the GMA suite, as in other localities, disseminated chromian spinel in serpentinites is usually more extensively altered and replaced than that in chromitite pods or magnesite-dominated rocks. Although the primary spinels in magnesite-rich samples are partly altered to ferritchromite, the Cr-magnetite rims observed in the serpentinite samples are absent. These features might be explained by the need for exchange of cations with surrounding silicate minerals to accomplish subsolidus replacement of chromian spinel and further modification to Cr-magnetite. If this is so, then preservation of fresh chrome spinel in magnesitebearing rocks implies that magnesite formation predates extensive spinel replacement. Furthermore, while transformation of chrome spinel to ferritchromite is defined by addition of $\mathrm{Fe}$ and loss of $\mathrm{Al}$ and $\mathrm{Mg}$, leading to increasing Cr\# and decreasing $\mathrm{Mg} \#$, it is also typically accompanied by addition of $\mathrm{Mn}$. However, the ferritchromite in serpentinite-hosted magnesite rocks in the GMA suite is depleted in $\mathrm{MnO}$, relative to the fresh chrome spinel. As carbonate minerals are highly favorable sinks for $\mathrm{Mn}$ (Deer et al. 1992), this feature also demonstrates that some carbonate formation predated spinel alteration in these rocks.

The minimum temperature of ferritchromite formation has been reported as $\sim 500^{\circ} \mathrm{C}$, which would make it an indicator mineral for lower-amphibolite facies metamorphism (Suita and Streider 1996; Mellini et al. 2005). Yet Evans and Frost (1975) and Suita and Streider (1996) report the transformation of chromian spinel to ferritchromite in greenschist facies rocks. Saumur and Hattori (2013) argue that ferritchromite, although rare in forearc peridotites, 
can form in response to a short-lived heating event during exhumation, in which case the remaining assemblage may remain at greenschist facies. In the GMA case, the observation of ferritchromite rimming primary chromian spinel, with sharp compositional gaps, likely indicates dominantly uppergreenschist facies metamorphism, with excursions to lower-amphibolite facies metamorphism (Evans and Frost 1975; Frost 1991; Suita and Streider 1996; Barnes and Roeder 2001; Arai et al. 2006). The occurrence of Cr-chlorite (kämmererite) around primary relics of chromian spinel reflects a further, lower-temperature episode of replacement of chromian spinel, below $300^{\circ} \mathrm{C}$ according to the chlorite thermometry results discussed above.

Age of Carbonation and Magnesite Formation. Throughout the Eastern Desert of Egypt, the serpentinized ultramafic sections of ophiolite sequences have commonly and conspicuously been affected by carbonation, perhaps in multiple stages, forming listwaenite, talc-carbonate rocks, serpentinite-hosted magnesite, and magnesite veins. However, the age of this alteration and the origin of the required $\mathrm{CO}_{2}{ }^{-}$ rich fluids have been controversial (e.g., Newton and Stern 1990; Stern and Gwinn 1990; Azer 2013; Boskabadi et al. 2017). In the GMA area, all the documented magnesite deposits, whether massive or vein type, are spatially associated with serpentinites and structurally related to shear zones and fault planes, suggesting close links between serpentinization, tectonic deformation, and magnesite formation. However, the existence of compositionally, texturally, and mineralogically distinct massive and vein-type magnesite indicates that hydrothermal carbonation occurred during two distinct metasomatic stages. The first carbonation stage, represented by the massive serpentinite-hosted magnesite, was coincident with serpentinization of the original ultramafic rocks shortly after their emplacement at a forearc spreading center, likely between 750 and $700 \mathrm{Ma}$ (Ali et al. 2010). The source of $\mathrm{CO}_{2}$ rich fluids was probably decomposition of subducted, carbonate-bearing sedimentary rocks.

The second carbonation stage, represented by the vein-type magnesite deposits in the GMA area, is more likely synchronous with obduction of the ophiolitic mantle section during the closure of the Mozambique Ocean, as a result of the collision of East and West Gondwana, between about 650 and $600 \mathrm{Ma}$ (Andresen et al. 2009; Eyal et al. 2014). Magnesite veins are commonly found near the base of obducted ophiolites, in regions that experienced significant shear deformation, both brittle and plastic. Fluids migrating into the hanging wall of the thrust faults accommodating obduction were likely derived from meteoric-hydrothermal fluids or from decomposition of carbonate-rich sediments in the footwall. Fractures opened during brittle deformation of the hanging wall provided pathways for such fluids, which precipitated magnesite as they migrated to lower pressures and temperatures.

\section{Summary}

1. The serpentinite exposure in the GMA area is a portion of a dismembered ophiolite, tectonically emplaced over an island arc volcanosedimentary succession.

2. The protoliths of the serpentinites and serpentinite-hosted magnesite rocks were forearctype, highly depleted harzburgites, on the basis of bastite and mesh textures; normative mineralogy; elevated whole-rock $\mathrm{Mg \#}, \mathrm{Cr}$, and $\mathrm{Ni}$ and low whole-rock $\mathrm{CaO}$ and $\mathrm{Al}_{2} \mathrm{O}_{3}$; high $\mathrm{NiO}$ content and $\mathrm{Mg \#}$ of relict olivine; and high Cr\# of fresh chromian spinel cores. They likely formed during a subduction-initiation episode leading to closure of the Mozambique Ocean in the Neoproterozoic.

3. Along shear zones and fault planes, the serpentinites host carbonate alteration assemblages. These are divided into (a) irregular magnesite masses containing serpentinite fragments, relict silicate minerals, and minor replacement by calcite or dolomite vug fillings and (b) pure magnesite veins.

4. Differences in whole-rock chemistry between massive serpentinite and serpentinite-hosted magnesite indicate that alteration is accompanied by removal of $\mathrm{MgO}, \mathrm{Cr}$, and $\mathrm{Ni}$, balanced by minor enrichment in $\mathrm{Fe}_{2} \mathrm{O}_{3}, \mathrm{CaO}, \mathrm{MnO}, \mathrm{Nb}, \mathrm{Ba}, \mathrm{Cu}, \mathrm{Pb}, \mathrm{Sr}$, and Zn.

5. The two modes of occurrences of magnesite indicate two stages of carbonate alteration: the magnesite masses represent deep-seated metasomatism during serpentinization, whereas the veins formed after serpentinization and during the obduction of the ophiolite.

\section{A C K N OW LEDG MENTS}

We acknowledge the logistical support provided by the Geological Sciences Department-National Research Centre, Egypt. P. D. Asimow acknowledges support from the US National Science Foundation, award EAR-1551433. We extend our appreciation to the Deanship of Scientific Research, King Saud University, for supporting this work through research group RG-1436-036. Special thanks to C. Ma for his help with the microprobe analyses. 


\section{REFERE N C E S C I T E D}

Abdel Aal, A. Y.; Farahat, E. S.; Hoinkes, G.; and ElMahalawi, M. M. 2003. Ophiolites from the Egyptian Shield: a case for a possible inter-arc origin. Oesterr. Geol. Ges. 148:81-83.

Abdel-Karim, A. M., and El-Shafei, S. A. 2018. Mineralogy and chemical aspects of some ophiolitic metaultramafics, central Eastern Desert, Egypt: evidences from chromites, sulphides and gangues. Geol. I. 53:580599. doi:10.1002/gj.2914.

Abd El-Rahman, Y.; Polat, A.; Dilek, Y.; Fryer, B. J.; El-Sharkawy, M.; and Sakran, S. 2009. Geochemistry and tectonic evolution of the Neoproterozoic incipient arc-forearc crust in the Fawakhir area, central Eastern Desert of Egypt. Precambrian Res. 175:116-134.

Abu El Ela, F. F., and Farahat, E. S. 2010. Neoproterozoic podiform chromitites in serpentinites of the Abu Meriewa-Hagar Dungash district, Eastern Desert, Egypt: geotectonic implications and metamorphism. Isl. Arc 19:151-164.

Abu-Jaber, N. S., and Kimberley, M. M. 1992a. Origin of ultramafic-hosted magnesite on Margarita Island, Venezuela. Miner. Depos. 27:234-241.

- 1992b. Origin of ultramafic-hosted vein magnesite deposits. Ore Geol. Rev. 7:155-191.

Ahmed, A. H.; Arai, S.; and Attia, A. K. 2001. Petrological characteristics of podiform chromitites and associated peridotites of the Pan African ophiolite complexes of Egypt. Miner. Depos. 36:72-84.

Ali, K. A.; Azer, M. K.; Gahlan, H. A.; Wilde, S. A.; Samuel, M. D.; and Stern, R. J. 2010. Age constraints on the formation and emplacement of Neoproterozoic ophiolites along the Allaqi-Heiani suture, south Eastern Desert of Egypt. Gondwana Res. 18:583-595.

Ali-Bik, W. M.; Taman, Z.; El Kalioubi, B.; and Abdel Wahab, W. 2012. Serpentinite-hosted talc-magnesite deposits of Wadi Barramiya area, Eastern Desert, Egypt: characteristics, petrogenesis and evolution. I. Afr. Earth Sci. 64:77-89.

Andresen, A.; El-Rus, M. A. A.; Myhre, P. I.; Boghdady, G. Y.; and Corfu, F. 2009. U-Pb TIMS age constraints on the evolution of the Neoproterozoic Meatiq Gneiss Dome, Eastern Desert, Egypt. Int. I. Earth Sci. 98:481497.

Anzil, P. A.; Guereschi, A. B.; and Martino, R. D. 2012. Mineral chemistry and geothermometry using relict primary minerals in the La Cocha ultramafic body: a slice of the upper mantle in the Sierra Chica of Córdoba, Sierras Pampeanas, Argentina. I. South Am. Earth Sci. 40:38-52.

Arai, S. 1975. Contact metamorphosed dunite-harzburgite complex in the Chugoku district, western Japan. Contrib. Mineral. Petrol. 52:1-16.

. 1980. Dunite-harzburgite-chromitite complexes as refractory residue in the Sangun-Yamaguchi zone, western Japan. I. Petrol. 21:141-165.
1992. Chemistry of chromian spinel in volcanic rocks as a potential guide to magma chemistry. Mineral. Mag. 56:173-184.

1997. Origin of podiform chromitites. I. Asian Earth Sci. 15:303-310.

Arai, S., and Abe, N. 1995. Reaction of orthopyroxene in peridotite xenoliths with alkali basalt melt and its implication for genesis of alpine-type chromitite. Am. Mineral. 80:1041-1047.

Arai, S.; Shimizu, Y.; Ismail, S. A.; and Ahmed, A. H. 2006. Low-T formation of high-Cr spinel with apparently primary chemical characteristics within podiform chromitite from Rayat, northeastern Iraq. Mineral. Mag. 70:499-508.

Arai, S., and Yurimoto, H. 1994. Podiform chromitites of the Tari-Misaka ultramafic complex, Southwest Japan, as mantle-melt interaction products. Econ. Geol. 89: $1279-1288$

-1995. Possible sub-arc origin of podiform chromitites. Isl. Arc 4:104-111.

Arif, M., and Jan, M. Q. 2006. Petrotectonic significance of the chemistry of chromite in the ultramaficmafic complexes of Pakistan. L. Asian Earth Sci. 27:628646.

Arndt, N.; Lesher, M. C.; and Barnes, S. J. 2008. Komatiite. Cambridge, Cambridge University Press, 467 p.

Azer, M. K. 2013. Evolution and economic significance of listwaenites associated with Neoproterozoic ophiolites in south Eastern Desert, Egypt. Geol. Acta 11(1):113128.

. 2014. Petrological studies of Neoproterozoic serpentinized ultramafics of the Nubian Shield: spinel compositions as evidence of the tectonic evolution of the Egyptian ophiolites. Acta Geol. Pol. 64:113-127.

Azer, M. K., and Khalil, A. E. S. 2005. Petrological and mineralogical studies of Pan-African serpentinites at Bir Al-Edeid area, central Eastern Desert, Egypt. I. Afr. Earth Sci. 43:525-536.

Azer, M. K.; Samuel, M. D.; Ali, K. A.; Gahlan, H. A.; Stern, R. J.; Ren, M.; and Moussa, H. E. 2013. Neoproterozoic ophiolitic peridotites along the AllaqiHeiani Suture, south Eastern Desert, Egypt. Mineral. Petrol. 107:829-848.

Azer, M. K., and Stern, R. J. 2007. Neoproterozoic (835$720 \mathrm{Ma})$ serpentinites in the Eastern Desert, Egypt: fragments of forearc mantle. I. Geol. 115:457-472.

Barnes, S. J., and Roeder, P. L. 2001. The range of spinel compositions in terrestrial mafic and ultramafic rocks. I. Petrol. 42:2279-2302.

Basta, E. Z.; Church, W. R.; Hafez, A. M. A.; and Basta, F. F. 1986. Proterozoic ophiolitic mélange and associated rocks of Gebel Ghadir area, Eastern Desert, Egypt. In Riad, S., and Baars, D. L., eds. Proceedings of the Fifth International Conference on Basement Tectonics: Cairo, Egypt, October 16-18, 1983. Salt Lake City, UT, 
International Basement Tectonics Association, p. 115124.

Basta, F. F.; Maurice, A. E.; Bakhit, B. R.; Ali, K. A.; and Manton, W. I. 2011. Neoproterozoic contaminated MORB of Wadi Ghadir ophiolite, NE Africa: geochemical and $\mathrm{Nd}$ and $\mathrm{Sr}$ isotopic constraints. I. Afr. Earth Sci. 59:227-242.

Beccaluva, L.; Coltori, M.; Giunta, G.; and Siena, F. 2004. Tethyan vs. Cordilleran ophiolites: a reappraisal of distinctive tectono-magmatic features of supra-subduction complexes in relation to subduction mode. Tectonophysics 393:163-174.

Beccaluva, L.; Macciota, G.; Piccardo, G. B.; and Zeda, O. 1989. Clinopyroxene composition of ophiolitic basalts as petrogenetic indicator. Chem. Geol. 77:165-182.

Bédard, J. H. 1991. Cumulate recycling and crustal evolution in the Bay of Islands Ophiolite. I. Geol. 99:225249.

1999. Petrogenesis of boninites from the Betts Cove ophiolite, Newfoundland, Canada: identification of subducted source components. I. Petrol. 40: 1853-1889.

Beinlich, A.; Plümper, O.; Hövelmann, J.; Austrheim, H.; and Jamtveit, B. 2012. Massive serpentinite carbonation at Linnajavri, N-Norway. Terra Nova 24:446-455.

Bernstein, S.; Szilas, K.; and Kelemen, P. B. 2013. Highly depleted cratonic mantle in West Greenland extending into diamond stability field in the Proterozoic. Lithos 168-169:160-172.

Bloomer, S. H.; Taylor, B.; MacLeod, C. J.; Stern, R. J.; Fryer, P.; Hawkins, J. W.; and Johnson, L. 1995. Early arc volcanism and ophiolite problem: a perspective from drilling in the western Pacific. In Taylor, B., and Natland, J., eds. Active margins and marginal basins of the western Pacific. Geophys. Monogr. 88: $1-30$.

Bonatti, E., and Michael, P. J. 1989. Mantle peridotites from continental rifts to ocean basins to subduction zones. Earth Planet. Sci. Lett. 91:297-311.

Bonatti, E.; Seyler, M.; Channell, J.; Girardeau, J.; and Mascle, G. 1990. Peridotites drilled from the Tyrrhenian Sea, ODP Leg 107. In Kastens, K. A.; Mascle, J.; Auroux, C.; Bonatti, E.; Broglia, C.; Channell, J.; Curzi, P.; et al., eds. Tyrrhenian Sea: sites 650-656. Proc. Ocean Drilling Program Sci. Results 107:37-47.

Boskabadi, A.; Pitcairn, I. K.; Broman, C.; Boyce, A.; Teagle, D. A. H.; Cooper, M. J.; Azer, M. K.; Mohamed, F. H.; Stern, R. J.; and Majka, J. 2017. Carbonate alteration of ophiolitic rocks in the Arabian-Nubian Shield of Egypt: sources and compositions of the carbonating fluid and implications for the formation of Au deposits. Int. Geol. Rev. 59(4):391-419.

Botros, N. S. 2002. Metallogeny of gold in relation to the evolution of the Nubian Shield in Egypt. Ore Geol. Rev. 19:137-164.

Bourdelle, F., and Cathelineau, M. 2015. Low-temperature chlorite geothermometry: a graphical representation based on a $T-R^{2+}$-Si diagram. Eur. I. Mineral. 27:617626.
Cathelineau, M., and Nieva, D. 1985. A chlorite solid solution geothermometer: the Los Azufres (Mexico) geothermal system. Contrib. Mineral. Petrol. 91:235244.

Church, W. R. 1988. Ophiolites, structures, and microplates of the Arabian-Nubian Shield: a critical comment. In El-Gaby, S., and Greiling, R. O., eds. The PanAfrican Belt of Northeast Africa and adjacent areas. Wiesbaden, Vieweg, p. 289-316.

Coleman, R. G. 1977. Ophiolites. Berlin, Springer, 229 p.

Deer, W. A.; Howie, R. A.; and Zussman, J. 1992. An introduction to the rock forming minerals. 2nd ed. London, Longman Scientific \& Technical, $696 \mathrm{p}$.

Dick, H. J. B., and Bullen, T. 1984. Chromian spinel as a petrogenetic indicator in abyssal and alpine-type peridotites and spatially associated lavas. Contrib. Mineral. Petrol. 86:54-76.

Dickey, J. S., Jr. 1976. A hypothesis of origin of podiform chromite deposits. In Irvine, T. N., ed. Chromium: its physicochemical behavior and petrologic significance. Oxford, Pergamon, p. 1061-1074.

Dilek, Y.; Moores, E.; Elthon, D.; and Nicolas, A., eds. 2000. Ophiolites and oceanic crust: new insights from field studies and the Ocean Drilling Program. Geol. Soc. Am. Spec. Pap. 349.

El Bayoumi, R. M. 1983. Ophiolites and mélange complex of Wadi Ghadir area, Eastern Desert, Egypt. Bull. Fac. Sci. King Abdul Aziz Univ. 6:329-342.

El Gaby, S.; List, F. K.; and Tehrani, R. 1988. Geology, evolution and metallogenesis of the Pan-African Belt in Egypt. In El Gaby, S., and Greiling, R. O., eds. The PanAfrican Belt of Northeast Africa and adjacent areas. Wiesbaden, Vieweg, p. 17-68.

El Ramly, M. F. 1972. A new geological map for the basement rocks in the Eastern and Southwestern Deserts of Egypt. Ann. Geol. Surv. Egypt 2:1-18.

El Sayed, M. M.; Furnes, H.; and Mohamed, F. H. 1999. Geochemical constraints on the tectonomagmatic evolution of the late Precambrian Fawakhir ophiolite, central Eastern Desert, Egypt. I. Afr. Earth Sci. 29:515-533.

El Sharkawy, M. A., and El Bayoumi, R. M. 1979. The ophiolites of Wadi Ghadir area, Eastern Desert, Egypt. Ann. Geol. Surv. Egypt 9:125-135.

Evans, B. W. 2010. Lizardite versus antigorite serpentinite: magnetite, hydrogen, and life(?). Geology 38: 879-882.

Evans, B. W., and Frost, B. R. 1975. Chrome-spinel in progressive metamorphism-a preliminary analysis. Geochim. Cosmochim. Acta 39:959-972.

Evans, B. W., and Trommsdorff, V. 1974. Stability of enstatites + talc, and $\mathrm{CO}_{2}$-metasomatism of metaperidotite, Val d'Efra, Lepontine Alps. Am. I. Sci. 274: 274-296.

Eyal, M.; Be'eri-Shlevin, Y.; Eyal, Y.; Whitehouse, M. J.; and Litvinovsky, B. 2014. Three successive Proterozoic island arcs in the northern Arabian-Nubian Shield: evidence from SIMS U-Pb dating of zircon. Gondwana Res. 25:338-357. 
Farahat, E. S. 2008. Chrome-spinels in serpentinites and talc carbonates of the El Ideid-El-Sodmein District, central Eastern Desert, Egypt: their metamorphism and petrogenetic implications. Chem. Erde 68:193-205.

Farahat, E. S.; El Mahalawi, M. M.; Hoinkes, G.; and Abdel Aal, A. Y. 2004. Continental back-arc basin origin of some ophiolites from the Eastern Desert of Egypt. Mineral. Petrol. 82:81-104.

Farahat, E. S.; Hoinkes, G.; and Mogessie, A. 2011. Petrogenetic and geotectonic significance of Neoproterozoic suprasubduction mantle as revealed by the Wizer ophiolite complex, central Eastern Desert, Egypt. Int. L. Earth Sci. 100:1433-1450.

Feig, S. T.; Koepke, J.; and Snow, J. E. 2006. Effect of water on tholeiitic basalt phase equilibria: an experimental study under oxidizing conditions. Contrib. Mineral. Petrol. 152:611-638.

Fiorentini, M. L.; Barnes, S. J.; Maier, W. D.; Burnham, O. M.; and Heggie, G. 2011. Global variability in the platinum-group element contents of komatiites. I. Petrol. 52:83-112.

Frost, B. R. 1975. Contact metamorphism of serpentinite, chloritic blackwall and rodingite at Paddy-Go-Easy Pass, central Cascades, Washington. I. Petrol. 16:272313.

2. 1991. Stability of oxide minerals in metamorphic rocks. In Lindsey, D. H., ed. Oxide minerals: petrologic and magnetic significance. Rev. Mineral. Geochem. 25:469-488.

Furnes, H.; de Wit, M.; and Dilek, Y. 2014. Four billion years of ophiolites reveal secular trends in oceanic crust formation. Geosci. Front. 5:571-603.

Gahlan, H.; Azer, M.; and Khalil, A. E. S. 2015. The Neoproterozoic Abu Dahr ophiolite, south Eastern Desert, Egypt: petrological characteristics and tectonomagmatic evolution. Mineral. Petrol. 109:611630.

Ghoneim, M. F.; Salem, I. A.; and Hamdy, M. M. 1999. On the petrogenesis of magnesite from Gebel El-Maiyit, central Eastern Desert, Egypt. In Hafez, A. M. A., ed. Geology of the Arab world, 1999: proceedings of the Fourth International Conference on Geology in the Arab World, Cairo University, Egypt, 1998. 1:575-593.

- 2003. Origin of magnesite veins in serpentinites from Mount El-Rubshi and Mount El-Maiyit, Eastern Desert, Egypt. Arch. Mineral. 54:41-63.

González-Jiménez, J. M.; Kerestedjian, T.; Proenza, J. A.; and Gervilla, F. 2009. Metamorphism on chromite ores from the Dobromirtsi ultramafic massif, Rhodope Mountains (SE Bulgaria). Geol. Acta 7:413-429.

Hamdy, M. M., and Gamal El Dien, H. M. 2017. Nature of serpentinization and carbonation of ophiolitic peridotites (Eastern Desert, Egypt): constrains from stable isotopes and whole rock geochemistry. Arab. I. Geosci. 10:429. doi:10.1007/s12517-017-3215-6.

Hamdy, M. M.; Harraz, H. Z.; and Aly, G. A. 2013. PanAfrican (intraplate and subduction-related?) metaso- matism in the Fawakhir ophiolitic serpentinites, central Eastern Desert of Egypt: mineralogical and geochemical evidences. Arab. I. Geosci. 6:13-33.

Hamdy, M. M., and Lebda, E. M. 2007. Metamorphism of ultramafic rocks at Gebel Arais and Gebel Malo Grim, Eastern Desert, Egypt: mineralogical and O-H stable isotopic constraints: Egypt. J. Geol. 51:105-124.

Hamlin, P. R., and Bonatti, E. 1980. Petrology of mantlederived ultramafics from the Owen fracture zone, northwest Indian Ocean: implications for the nature of the oceanic upper mantle. Earth Planet. Sci. Lett. 48: 49-65.

Hattori, K. H., and Guillot, S. 2007. Geochemical character of serpentinites associated with high- to ultrahigh-pressure metamorphic rocks in the Alps, Cuba, and the Himalayas: recycling of elements in subduction zones. Geochem. Geophys. Geosyst. 8:Q09010. doi:10.1029/2007GC001594.

Hey, M. H. 1954. A new review of the chlorites. Mineral. Mag. 30:272-292.

Hillier, S., and Velde, B. 1991. Octahedral occupancy and the chemical composition of diagenetic (low-temperature) chlorites. Clav Miner. 26:149-168.

Hirose, K., and Kawamoto, T. 1995. Hydrous partial melting of lherzolite at $1 \mathrm{GPa}$ : the effect of $\mathrm{H}_{2} \mathrm{O}$ on the genesis of basaltic magmas. Earth Planet. Sci. Lett. 133:463-473.

Ishii, T.; Robinson, P.; Maekawa, H.; and Fiske, R. 1992. Petrological studies of peridotites from diapiric serpentine seamounts in the Izu-Ogasawara-Mariana forearc, Leg 125. In Fryer, P.; Pearce, J. A.; Stokking, L. B.; Ali, J. R.; Arculus, R.; Ballotti, D.; Burke, M. M.; et al., eds. Bonin-Mariana region: sites 778-786. Proc. Ocean Drilling Program Sci. Results 125:445-485.

Ishimaru, S.; Ishida, Y.; Shirasaka, M.; and Okrugin, V. M. 2007. Melting and multi-stage metasomatism in the mantle wedge beneath a frontal arc inferred from highly depleted peridotite xenoliths from the Avacha Volcano, southern Kamchatka. I. Petrol. 48:395433.

Jan, M. Q., and Windley, B. F. 1990. Chromian spinelsilicate chemistry in ultramafic rocks of the Jijal complex, northwest Pakistan. I. Petrol. 31:667-715.

Johannes, W. 1970. Zur Entstehung von Magnesitvorkommen. Neues Jahrb. Mineral. Abh. 113:274-325.

Johnson, K. T. M.; Dick, H. J. B.; and Shimizu, N. 1990. Melting in the oceanic upper mantle: an ion microprobe study of diopsides in abyssal peridotites. I. Geophys. Res. 95:2661-2678.

Johnson, L. E., and Fryer, P. 1990. The first evidence for MORB-like lavas from the outer Mariana forearc: geochemistry, petrography and tectonic implications. Earth Planet. Sci. Lett. 100:304-316.

Juteau, T.; Berger, E.; and Cannat, M. 1990. Serpentinized, residual mantle peridotites from the M. A. R. median valley, ODP hole $670 \mathrm{~A}\left(21^{\circ} 10^{\prime} \mathrm{N}, 45^{\circ} 02^{\prime} \mathrm{W}\right.$, Leg 109): primary mineralogy and geothermometry. In Detrick, R. S.; Honnorez, J.; Adamson, A. C.; Brass, G. W.; 
Gillis, K. M.; Humphris, S. E.; Mevel, C.; et al., eds. MidAtlantic Ridge: sites 648-649, sites 395, 648, 669, and 670. Proc. Ocean Drilling Program Sci. Results 106/ 109:27-45.

Kadir, S.; Kolayli, H.; and Eren, M. 2013. Genesis of sedimentary- and vein-type magnesite deposits at Kop Mountain, NE Turkey. Turk. J. Earth Sci. 22:98114.

Kamenetsky, V.; Crawford, A. J.; and Meffre, S. 2001. Factors controlling chemistry of magmatic spinel: an empirical study of associated olivine, Cr-spinel and melt inclusions from primitive rocks. I. Petrol. 42:655-671.

Kelemen, P. B. 1990. Reaction between ultramafic rock and fractionating basaltic magma I. Phase relations, the origin of calc-alkaline magma series and the formation of discordant dunite. I. Petrol. 31:51-98.

Khalil, A. E. S., and Azer, M. K. 2007. Supra-subduction affinity in the Neoproterozoic serpentinites in the Eastern Desert, Egypt: evidence from mineral composition. I. Afr. Earth Sci. 49:136-152.

Khalil, A. E. S.; Obeid, M. A.; and Azer, M. K. 2014. Serpentinized peridotites at the north part of Wadi Allaqi district (Egypt): implications for the tectonomagmatic evolution of fore-arc crust. Acta Geol. Sin. 88(5):1421-1436.

Khedr, M. Z., and Arai, S. 2013. Origin of Neoproterozoic ophiolitic peridotites in south Eastern Desert, Egypt, constrained from primary mantle mineral chemistry. Mineral. Petrol. 107:807-828.

Khudeir, A. A.; El Haddad, M. A.; and Leake, B. E. 1992. Compositional variation in chromite from the Eastern Desert. Mineral. Mag. 56:567-574.

Kranidiotis, P., and MacLean, W. H. 1987. The systematics of chlorite alteration at the Phelps Dodge massive sulfide deposit, Matagami, Quebec. Econ. Geol. 82:18981911.

Kröner, A.; Todt, W.; Hussein, I. M.; Mansour, M.; and Rashwan, A. A. 1992. Dating of late Proterozoic ophiolites in Egypt and the Sudan using the single grain zircon evaporation technique. Precambrian Res. 59:1532.

Lago, B. L.; Rabinowicz, M.; and Nicolas, A. 1982. Podiform chromite ore bodies: a genetic model. I. Petrol. 23:103-125.

Lugli, S.; Morteani, G.; and Blamart, D. 2002. Petrographic, REE, fluid inclusion and stable isotope study of magnesite from the Upper Triassic Burano Evaporites (Secchia Valley, northern Apennines): contributions from sedimentary, hydrothermal and metasomatic sources. Miner. Depos. 37:480-494.

Matsukage, K. N., and Kubo, K. 2003. Chromian spinel during melting experiments of dry peridotite (KLB-1) at 1.0-2.5 GPa. Am. Mineral. 88:1271-1278.

McElduff, B., and Stumpfl, E. F. 1991. The chromite deposits of the Troodos complex, Cyprus-evidence for the role of a fluid phase accompanying chromite formation. Miner. Depos. 26:307-318.
Mellini, M.; Rumori, C.; and Viti, C. 2005. Hydrothermally reset magmatic spinels in retrograde serpentinites: formation of "ferritchromit" rims and chlorite aureoles. Contrib. Mineral. Petrol. 149:266-275.

Möller, P. 1989. Minor and trace elements in magnesite. In Möller, P., ed. Magnesite: geology, mineralogy, geochemistry, formation of Mg-carbonates. Monogr. Ser. Miner. Depos., no. 28. Berlin, Borntraeger, p. 173-195.

Moody, J. B. 1976. Serpentinization: a review. Lithos 9:125-138.

Moores, E. M.; Kellogg, L. H.; and Dilek, Y. 2000. Tethyan ophiolites, mantle convection, and tectonic "historical contingency": a resolution of the "ophiolite conundrum." In Dilek, Y.; Moores, E. M.; Elthon, D.; and Nicolas, A., eds. Ophiolites and oceanic crust: new insights from field studies and the Ocean Drilling Program. Geol. Soc. Am. Spec. Pap. 349:3-12.

Morimoto, N.; Fabries, J.; Ferguson, A. K.; Ginzburg, I.; Ross, M.; Seifert, F. A.; and Zussman, J. 1988. Nomenclature of pyroxenes. Mineral. Mag. 52:535-550.

Müntener, O.; Kelemen, P. B.; and Grove, T. L. 2001. The role of $\mathrm{H}_{2} \mathrm{O}$ during crystallization of primitive arc magmas under uppermost mantle conditions and genesis of igneous pyroxenites: an experimental study. Contrib. Mineral. Petrol. 141:643-658.

Müntener, O., and Ulmer, P. 2006. Experimentally derived high-pressure cumulates from hydrous arc magmas and consequences for the seismic velocity structure of island arc crust. Geophys. Res. Lett. 33:L21308. doi:10 .1029/2006GL027629.

Murck, B. W., and Campbell, I. H. 1986. The effect of temperature, oxygen fugacity and melt composition on the behavior of chromium in basic and ultrabasic melts. Geochim. Cosmochim. Acta 50:1871-1887.

Murton, B. J. 1989. Tectonic controls on boninite genesis. In Saunders, A. D., and Norry, M. J., eds. Magmatism in the ocean basins. Geol. Soc. Lond. Spec. Publ. 42:347377.

Newton, R. C., and Stern, R. J. 1990. A late Precambrian $\mathrm{CO}_{2}$ "event." Geol. Soc. Am. Abstr. Program 22(7):A190.

Nicolas, A. 1989. Structure of ophiolites and dynamics of oceanic lithosphere, Dordrecht, Kluwer, 367 p.

Obeid, M. A.; Khalil, A. E. S.; and Azer, M. K. 2016. Mineralogy, geochemistry and geotectonic significance of the Neoproterozoic ophiolite of Wadi Arais area, south Eastern Desert, Egypt. Int. Geol. Rev. 58: 687-702.

Ohara, Y.; Stern, R. J.; Ishii, T.; Yurimoto, $\mathrm{H}_{\text {; }}$ and Yamazaki, T. 2002. Peridotites from the Mariana Trough: first look at the mantle beneath an active back-arc basin. Contrib. Mineral. Petrol. 143:1-18.

Okamura, H.; Arai, S.; and Kim, Y. U. 2006. Petrology of forearc peridotite from the Hahajima Seamount, the Izu-Bonin arc, with special reference to chemical characteristics of chromian spinel. Mineral. Mag. 70:15-26.

Pal, T., and Mitra, S. 2004. P-T- $\mathrm{fO}_{2}$ controls on a partly inverse chromite-bearing ultramafic intrusive: an 
evaluation from the Sukinda Massif, India. I. Asian Earth Sci. 22:483-493.

Pallister, J. S.; Stacey, J. S.; Fischer, L. B.; and Premo, W. R. 1988. Precambrian ophiolites of Arabia: geologic settings, U-Pb geochronology, $\mathrm{Pb}$-isotope characteristics, and implications for continental accretion. Precambrian Res. 38:1-54.

Parkinson, I. J., and Pearce, J. A. 1998. Peridotites from the Izu-Bonin-Mariana forearc (ODP Leg 125): evidence for mantle melting and melt-mantle interaction in a suprasubduction zone setting. I. Petrol. 39:1577-1618.

Pearce, J. A. 2003. Supra-subduction zone ophiolites: the search for modern analogues. In Dilek, Y., and Newcomb, S., eds. Ophiolite concept and the evolution of geological thought. Geol. Soc. Am. Spec. Pap. 373:269-294.

Pearce, J. A.; Barker, P. F.; Edwards, S. J.; Parkinson, I. J.; and Leat, P. T. 2000. Geochemistry and tectonic significance of peridotites from the South Sandwich arc-basin system, South Atlantic. Contrib. Mineral. Petrol. 139: 36-53.

Pohl, W. 1990. Genesis of magnesite deposits-models and trends. Geol. Rundsch. 79:291-299.

Proenza, J. A.; Ortega-Gutiérrez, F.; Camprubí, A.; Tritlla, J.; Elías-Herrera, M.; and Reyes-Salas, M. 2004. Paleozoic serpentinite-enclosed chromitites from Tehuitzingo (Acatlán Complex, southern Mexico): a petrological and mineralogical study. I. South Am. Earth Sci. 16:649-666.

Proenza, J. A.; Zaccarini, F.; Escayola, M.; Cábana, C.; Shalamuk, A.; and Garuti, G. 2008. Composition and textures of chromite and platinum group minerals in chromitites of the western ophiolitic belt from Pampean ranges of Córdoba, Argentina. Ore Geol. Rev. 33 (1):32-48.

Ries, A.C.; Shackleton, R.; Graham, R.H.; and Fitches, W. R. 1983. Pan-African structures, ophiolites and mélanges in the Eastern Desert of Egypt: a traverse at $26^{\circ} \mathrm{N}$. L. Geol. Soc. Lond. 140:75-95.

Roberts, S. 1988. Ophiolitic chromitite formation: a marginal basin phenomenon? Econ. Geol. 83:1034-1036.

Roberts, S., and Neary, C. 1993. Petrogenesis of ophiolitic chromitite. In Prichard, H. M.; Alabaster, T.; Harris, N. B. W.; and Neary, C. R., eds. Magmatic processes and plate tectonics. Geol. Soc. Lond. Spec. Publ. 76:257-272.

Saleh, G. M. 2006. The chromite deposits associated with ophiolite complexes, Southeastern Desert, Egypt: petrological and geochemical characteristics and mineralization. Chin. I. Geochem. 25:307-317.

Salem, I. A.; Ghoneim, M. F.; Zahran, A. A.; and Hamdy, M. M. 1997. Petrology and genesis of the ultramafic-hosted vein magnesite deposits at G. ElRubshi, central Eastern Desert, Egypt. Conference on Geochemistry, 3rd (Alexandria, 1997), Proc. Alexandria, Alexandria University, p. 241-267.

Saumur, B. M., and Hattori, K. 2013. Zoned Cr-spinel and ferritchromite alteration in forearc mantle serpentinites of the Rio San Juan Complex, Dominican Republic. Mineral. Mag. 77:117-136.
Shackleton, R. M. 1994. Review of late Proterozoic sutures, ophiolitic mélanges and tectonics of eastern Egypt and north Sudan. Geol. Rundsch. 83:537-546.

Shackleton, R. M.; Ries, A. C.; Graham, R. H.; and Fitches, W. R. 1980. Late Precambrian ophiolitic mélange in the Eastern Desert of Egypt. Nature 285:472-474.

Shervais, J. W.; Kimbrough, D. L.; Renne, P. R.; Hanan, B. B.; Murchey, B.; Snow, C. A.; Schuman, M. M. Z.; and Beaman, J. 2004. Multi-stage origin of the Coast Range ophiolite, California: implications for the life cycle of supra-subduction zone ophiolites. Int. Geol. Rev. 46: 289-315.

Shukri, N. M., and Lotfi, M. 1959. The geology of the Bir Barramiya area. Bull. Fac. Sci. Cairo Univ. 34:83130.

Sobolev, N. V., and Logvinova, A. M. 2005. Significance of accessory chrome spinels in identifying serpentinite paragenesis. Int. Geol. Rev. 47:58-64.

Stern, R. J. 1994. Arc assembly and continental collision in the Neoproterozoic East African Orogen: implications for the consolidation of Gondwanaland. Annu. Rev. Earth Planet. Sci. 22:319-351.

Stern, R. J., and Gwinn, C. J. 1990. Origin of late Precambrian intrusive carbonates, Eastern Desert of Egypt and Sudan: C, O, and Sr isotopic evidence. Precambrian Res. 46:259-272.

Stern, R. J., and Hedge, C. E. 1985. Geochronologic constraints on late Precambrian crustal evolution in the Eastern Desert of Egypt. Am. J. Sci. 285:319-351.

Stern, R. J.; Johnson, P. R.; Kröner, A.; and Yibas, B. 2004. Neoproterozoic ophiolites of the Arabian-Nubian Shield. In Kusky, T. M., ed. Precambrian ophiolites and related rocks. Dev. Precambrian Geol. no. 13. Amsterdam, Elsevier, p. 95-128.

Suita, M. T., and Streider, A. J. 1996. Cr-spinels from Brazilian mafic-ultramafic complexes: metamorphic modifications. Int. Geol. Rev. 38:245-267.

Szilas, K.; Van Hinsberg, V. J.; Creaser, R. A.; and Kisters, A. F. M. 2014. The geochemical composition of serpentinites in the Mesoarchaean Tartoq Group, SW Greenland: harzburgitic cumulates or melt-modified mantle? Lithos 198-199:103-116.

Takahashi, E.; Uto, K.; and Schilling, J. G. 1987. Primary magma compositions and $\mathrm{Mg} / \mathrm{Fe}$ ratios of their mantle residues along mid-Atlantic ridge $29^{\circ} \mathrm{N}$ to $73^{\circ} \mathrm{N}$. Tech. Rep. A9. Okayama, Institute of Studies Earth's Interior, Okayama University, $14 \mathrm{p}$.

Takla, M. A.; El Sharkawi, M. A.; and Basta, F. F. 1982. Petrology of the basement rocks of Gebel MohagaraGhadir area, Eastern Desert, Egypt. Ann. Geol. Surv. Egypt 12:121-140.

Thalhammer, O. A. R.; Prochaska, W.; and Mühlhans, H. W. 1990. Solid inclusions in chrome spinels and platinum group element concentrations from the Hochgrössen and Kraubath ultramafic massifs (Austria). Contrib. Mineral. Petrol. 105:66-80.

Trommsdorff, V.; López Sánchez-Vizcaíno, V.; GómezPugnaire, M. T.; and Müntener, O. 1998. High pressure breakdown of antigorite to spinifex-textured olivine 
and orthopyroxene, SE Spain. Contrib. Mineral. Petrol. 132:139-148.

Umino, S., and Kushiro, I. 1989. Experimental studies on boninite petrogenesis. In Crawford, A. J., ed. Boninites and related rocks. London, Unwin Hyman, p. 89-111.

Wood, B. J., and Turner, S. P. 2009. Origin of primitive high-Mg andesite: constraints from natural examples and experiments. Earth Planet. Sci. Lett. 283:5966.

Yavuz, F.; Kumral, M.; Karakaya, N.; Karakaya, M. C.; and Yildirım, D. K. 2015. A Windows program for chlorite calculation and classification. Comput. Geosci. 81:101-113.

Zachmann, D. W., and Johannes, W. 1989. Cryptocrystalline magnesite. In Möller, P., ed. Magnesite: geology, mineralogy, geochemistry and formation of
Mg-carbonates. Monogr. Ser. Miner. Depos., no. 28. Berlin, Borntraeger, p. 15-28.

Zedef, V.; Russell, M. J.; and Fallick, A. E. 2000. Genesis of vein stockwork and sedimentary magnesite and hydromagnesite deposits in the ultramafic terranes of southwestern Turkey: a stable isotope study. Econ. Geol. 95:429-446.

Zhou, M. F.; Robinson, P. T.; Malpas, J.; and Li, Z. 1996. Podiform chromite in the Luobusa ophiolite (southern Tibet): implication for melt-rock interaction and chromite segregation in the upper mantle. I. Petrol. 37:3-21.

Zimmer, M.; Kröner, A.; Jochum, K. P.; Reischmann, T.; and Todt, W. 1995. The Gabal Gerf complex: a Precambrian N-MORB ophiolite in the Nubian Shield, NE Africa. Chem. Geol. 123:29-51. 